Article

\title{
Evaluation of In-Package Atmospheric Dielectric Barrier Discharge Cold Plasma Treatment as an Intervention Technology for Decontaminating Bulk Ready-To-Eat Chicken Breast Cubes in Plastic Containers
}

\author{
Eun Song Lee ${ }^{1,+}$, Chan-Ick Cheigh ${ }^{2,+}{ }^{\mathbb{C}}$, Joo Hyun Kang ${ }^{1}$, Seung Young Lee ${ }^{1}$ and \\ Sea C. Min ${ }^{1, *(\mathbb{D}}$ \\ 1 Department of Food Science and Technology, Seoul Women's University, Seoul 01797, Korea; \\ pineles@naver.com (E.S.L.); as03226@naver.com (J.H.K.); seung_30@naver.com (S.Y.L.) \\ 2 Department of Food and Food Service Industry, Kyungpook National University, Sangju 37131, Korea; \\ cic@knu.ac.kr \\ * Correspondence: smin@swu.ac.kr; Tel.: +82-2-970-5635 \\ + These authors contributed equally to the work.
}

Received: 5 August 2020; Accepted: 7 September 2020; Published: 10 September 2020

Featured Application: In-package atmospheric cold plasma treatment shows potential as an intervention technology increasing microbiological safety and shelf-life of packaged ready-to-eat chicken products, leading to toxicological safety overall.

\begin{abstract}
This article evaluates the effects of in-package atmospheric dielectric barrier discharge cold plasma (ADCP) treatment on microbial inactivation, nitrate and nitrite contents, oral toxicity, and storage quality of protein-coated boiled chicken breast cubes (CBCs). ADCP treatment at $24 \mathrm{kV}$ for 3 min inactivated natural mesophilic aerobic bacteria, Salmonella, and Tulane virus in CBCs by 0.7 $\pm 0.2,1.4 \pm 0.1 \log \mathrm{CFU} / \mathrm{cube}$, and $1.1 \pm 0.2 \log$ PFU/cube, respectively. ADCP treatment did not affect the nitrite content of CBCs $(p>0.05)$. Furthermore, the hematological and blood biochemical parameters from toxicity tests indicated the toxicological safety of ADCP-treated CBCs. Microbial counts of natural bacteria and Salmonella in ADCP-treated CBCs were lower than the ADCP-untreated CBCs by 0.7-0.9 and 1.4-1.7 log CFU/cube, respectively, throughout post-treatment storage at $4{ }^{\circ} \mathrm{C}$ for $21 \mathrm{~d}$. ADCP treatment did not alter the $\mathrm{pH}$, color, total volatile basic nitrogen, lipid oxidation, and tenderness of $\mathrm{CBC}$ during storage at 4 and $24^{\circ} \mathrm{C}$, and did not change the sensory properties of CBCs following a $3 \mathrm{~d}$ storage period at $4{ }^{\circ} \mathrm{C}(p>0.05)$. Thus, ADCP treatment has the potential to be applied as a method to increase the microbiological safety of packaged ready-to-eat chicken products, leading to overall toxicological safety.
\end{abstract}

Keywords: cold plasma; microbial inactivation; oral toxicity; storage quality; chicken breast

\section{Introduction}

Reports of food poisoning caused by ready-to-eat (RTE) meat products have increased with the increasing demand for RTE meat products [1,2]. According to the Center for Disease Control and Prevention (CDC), 290 cases of food poisoning due to ingesting chicken meat products were reported in 2019- of which, 105 cases and two deaths were caused by Salmonella poisoning. Furthermore, chicken meat products were associated with 24 cases of Norovirus food poisoning during the period of 2013-2017 [3]. 
Recent studies have proactively investigated the efficacy of cold plasma treatment as an in-package microbial disinfection method that prevents post-process contamination [1,4-8]. Among the various methods used to generate cold plasma, atmospheric dielectric barrier discharge (ADCP) has attracted the attention of the food industry, as it allows the formation of cold plasma inside plastic packages, making cold plasma treatment an in-package treatment $[7,9,10]$. Cold plasma comprises electrons and ultraviolet photons generated in plasma, as well as reactive oxygen species (ROS) and reactive nitrogen species (RNS), such as single oxygen $\left({ }^{1} \mathrm{O}_{2}\right)$, superoxide anion $\left(\mathrm{O}_{2}{ }^{\bullet-}\right)$, hydroxyl $\left(\mathrm{HO}_{2}{ }^{\bullet-}\right)$, hydroxyl radical $\left({ }^{\bullet} \mathrm{OH}\right)$, hydrogen peroxide $\left(\mathrm{H}_{2} \mathrm{O}_{2}\right)$, ozone $\left(\mathrm{O}_{3}\right)$, alkoxyl $\left(\mathrm{RO}{ }^{\bullet}\right)$, peroxyl $\left(\mathrm{ROO}^{\bullet}\right)$, peroxynitrite $\left(\mathrm{ONOO}^{-}\right)$, nitric oxide $\left(\mathrm{NO}^{\bullet}\right)$, nitrogen dioxide radical $\left({ }^{\bullet} \mathrm{NO}_{2}\right)$, alkylperoxynitrite (ROONO) and peroxynitrous acid (OONOH) [11]. These can destroy chemical bonds in the microbial cell membrane by collision, which erodes the cell membrane through etching [10]. These can also enter the cells to react with proteins, lipids, and DNA, thereby non-thermally inactivating the microorganism [5,6,10,12].

Nevertheless, reactive species that are produced upon cold plasma treatment may influence the chemical properties of food products. This should be investigated prior to the application of cold plasma technologies in the food industry [13]. Wende et al. reported that the application of a cold argon plasma jet to V79 cells for 3 min did not increase genotoxicity [14]. Han et al. reported that acute and subacute toxicity tests using defatted soybean meal-based biopolymer film following microwave cold plasma treatment verified the safety of the treatment [13]. Despite such reports, further studies may be warranted to positively confirm that ADCP treatment of food products does not generate harmful by-products.

Moutiq et al. [1] subjected fresh chicken breast samples to ADCP treatment (at $100 \mathrm{kV}, 5 \mathrm{~min}$ ), and reported that indigenous mesophiles and Enterobacteriaceae in the fresh chicken breast were inactivated by $1.5 \log$ CFU/g, while shelf-life was increased by six more days [1]. Furthermore, Wang et al. showed that microbial populations in raw chicken fillets treated with ADCP $(80 \mathrm{kV}$ for 3, 6, or 9 min) were reduced by approximately $1-1.5 \log \mathrm{CFU} / \mathrm{g}$ after the samples were stored at $4{ }^{\circ} \mathrm{C}$ for $3 \mathrm{~d}$ [15]. Most such studies, however, focused on fresh poultry meat. Studies regarding the effect of cold plasma treatment on RTE-type processed poultry meat and quality-related properties during storage are lacking.

In this study, we have determined ADCP treatment conditions based on its efficacy in inactivating Salmonella in boiled chicken breast cubes (CBCs), investigated the effect of ADCP treatment on the inactivation of Tulane virus (TV), a surrogate of human norovirus, and the concentrations of nitrate and nitrite, determined toxicological safety of ADCP-treated CBCs, and verified the effect of ADCP treatment on the storage stability of CBCs by studying the growth of Salmonella and natural mesophilic bacteria, as well as $\mathrm{pH}$, color, total volatile basic nitrogen (TVBN), thiobarbituric acid reactive substances (TBARS), tenderness and sensory properties of CBCs during storage at 4 and $24{ }^{\circ} \mathrm{C}$.

\section{Materials and Methods}

\subsection{Materials}

Raw chicken breasts were purchased from Nobrand (Gunsan, Korea), and stored at $-20{ }^{\circ} \mathrm{C}$ until needed for subsequent experiments. Dried CBCs for ADCP treatment were packaged using a commercial polyethylene terephthalate (PET) container $(230 \mathrm{~mL}, 100 \times 100 \times 35 \mathrm{~mm}, 0.28 \mathrm{~mm}$ thickness; Samboopack, Incheon, Korea). Sodium nitrate and sodium nitrite used as reference materials for nitrate and nitrite analyses were purchased from Sigma Aldrich, St. Louis, MO, USA).

\subsection{Chicken Breast Sample Preparation}

CBCs were prepared according to the methods described by Roh et al. [16]. Frozen raw chicken breast $(1 \mathrm{~kg})$ was placed in a common household pot and boiled at $99{ }^{\circ} \mathrm{C}$ for $15 \mathrm{~min}$-this was determined based on those used for the commercial preparation of chicken breast salad $\left(80-100{ }^{\circ} \mathrm{C}\right.$, $15-20 \mathrm{~min})$. Boiled CBCs were cut into $1.5 \times 1.5 \times 1.5 \mathrm{~cm}$ sizes using a razor sterilized using $70 \%(v / v)$ ethanol inside a biohazard hood (Hanbaek Co., Ltd., HB-402, Bucheon, Korea). Immediately after 
cutting, the CBCs were coated on all sides with whey protein isolate (WPI) coating solution (BiPRO ${ }^{\circledR}$, Davisco Foods International, Le Sueur, MN, USA), prepared according to the methods described by McHugh and Krochta [17]. The coating solution was prepared by heating $10 \%(w / w)$ WPI aqueous solution in a $90{ }^{\circ} \mathrm{C}$ water bath for $30 \mathrm{~min}$ and mixing it with glycerol $(5 \%, w / w)$ after cooling down to $23^{\circ} \mathrm{C}$. Each CBC was immersed in $20 \mathrm{~mL}$ of WPI coating solution for $1 \mathrm{~min}$, and dried inside a biohazard hood for $2 \mathrm{~h}$. The coating process was repeated twice. Dried CBCs, meant for subsequent ADCP treatment, were packaged in two layers (nine cubes on the bottom and six cubes on the top layer) in the commercial PET container that had been sprayed with $70 \%$ ethanol, dried and washed with sterilized distilled water, and dried in a biohazard hood.

\subsection{Microbial Inoculum Preparation}

The Salmonella strains used in this study were S. Enteritidis (CCARM 8040), S. Montevideo (CCARM 8052), and S. Typhimurium DT 104. S. Enteritidis and S. Montevideo, obtained from Culture Collection of Antimicrobial Resistant Microbes (Seoul Women's University, Seoul, Korea), and S. Typhimurium DT 104, obtained from Agricultural Biotechnology Culture Collection (Seoul National University, Seoul, Korea). Each Salmonella strain was cultured in tryptic soy broth (TSB; BD, Franklin Lakes, NJ, USA) at $37^{\circ} \mathrm{C}$ for $24 \mathrm{~h}$; this process was repeated twice. Cultured strains were centrifuged $(4000 \times g$ for $5 \mathrm{~min})$ and washed twice with $0.1 \%(w / v)$ peptone water. After washing, the three strains were mixed in equal volume to prepare a Salmonella cocktail, the concentration of which was checked by spreading on xylose-lysine-desoxycholate agar (BD).

TV is used as a surrogate for human norovirus $[9,18,19]$. The TV inoculum was prepared, as described by Roh et al. [8]. TV obtained from Cincinnati Children's Hospital Medical Center (Cincinnati, $\mathrm{OH}$, USA), was propagated in a monkey kidney cell line (LLC-MK2) from Korea Cancer Center Hospital (Seoul, Korea). The M199 medium (Gibco) supplemented with 10\% heat-inactivated fetal bovine serum (FBS; Gibco, NY, USA) and 1\% antibiotic-antimycotic solution (Cellgro Mediatech Inc.; Herndon, VA, USA) was used as the cell growth medium. The cells were cultured in a humidified incubator at $37{ }^{\circ} \mathrm{C}$ under conditions of $95 \%$ air and $5 \% \mathrm{CO}_{2}$, infected with $\mathrm{TV}$, and incubated for $2 \mathrm{~d}$ in a $5 \%$ $\mathrm{CO}_{2}$ atmosphere, as described by Min et al. [9]. TV was harvested following incubation via three freeze-thaw cycles and centrifugation, following which the virus was used as an inoculum.

In each time of inoculation, 20 and 3 CBCs were immersed in $600 \mathrm{~mL}$ of Salmonella cocktail and $50 \mathrm{~mL}$ of TV inoculum, respectively, and stirred for 3-min for inoculation. Following inoculation, CBCs were dried in a biohazard hood for $2 \mathrm{~h}$, and then used as samples. The concentrations of Salmonella and TV on dried CBCs were $5.1 \pm 0.1 \log$ CFU/cube and $3.6 \pm 0.3 \log$ PFU/cube, respectively.

\subsection{ADCP Treatment}

ADCP treatment was carried out using a device (Renosem, Bucheon, Korea) described by Kim et al. [4], which forms a plasma field between two aluminum electrodes $(20 \times 16 \mathrm{~cm}$, AL6061; Kwang-lim Co., Ltd., Hwasung, Korea). Packaged samples (15 CBCs) were placed in the gap between the upper electrode and the dielectric barrier (borosilicate glass, $29 \times 25 \mathrm{~cm}$, thickness $0.4 \mathrm{~cm}$ ). The electrodes were connected to a power supply delivering alternating current (max. $40 \mathrm{kV}, 60 \mathrm{~Hz}$ ). Voltage was measured using a high-voltage electrical probe (EP-50, Pulse Electronic Engineering Co., Ltd., Noda, Japan). The output of the probe was monitored on a digital oscilloscope (TDS-3012b Oscilloscope, Tektronix, Beaverton, OR, USA). The distance between the top surface of the packaged sample and the upper electrode was set at $0.5 \mathrm{~cm}$. The voltage and time for ADCP treatment were determined as those causing neither dielectric breakdown (arc) of CDCs nor any change in color, while inactivating Salmonella. During treatment, the container was shaken using insulated bars connected to a digital reciprocating shaker (Daihan Scientific Co., Ltd., Daejeon, Korea) moving at $300 \mathrm{rpm}$. $\mathrm{ADCP}$-untreated samples were prepared by packaging $\mathrm{CBC}$ s in the PET container and placing next to the ADCP treatment system for a time period that was identical to that of ADCP treatment. 


\subsection{Microbial Analysis}

Two CBCs were randomly chosen from each treatment package containing $15 \mathrm{CBCs}$, whereupon each $\mathrm{CBC}$ was blended with $10 \mathrm{~mL}$ of $0.1 \%$ peptone water to prepare an analytical sample. A preliminary study using the same ADCP treatment system and treatment method (i.e., shaking) as those of the current study demonstrated that the effect of the treatment against Salmonella was uniform, irrespective of the positions of grape tomatoes (22 tomatoes stacked in two layers) in a plastic clamshell package [20]. To analyze its effect on indigenous mesophilic bacteria and Salmonella, one CBC and $10 \mathrm{~mL}$ of $0.1 \%$ peptone water were placed in a stomacher bag $(130 \mathrm{~mL}$, Nasco Whirl-Pak) and hand-rubbed for $3 \mathrm{~min}$. The rubbed solution was diluted, spread on plate count agar and xylose-lysine-desoxycholate agar, and cultured at $37^{\circ} \mathrm{C}$ for 48 and $24 \mathrm{~h}$ prior to colony counting, respectively.

To analyze the effect on TV, one CBC and $10 \mathrm{~mL}$ of serum free M199 media were placed in a stomacher bag and hand-rubbed for $3 \mathrm{~min}$. The rubbed solution was subjected to decompression filtration using a $0.22 \mu \mathrm{m}$ filter system (Corning, Corning, NY, USA) to prepare the virus solution for analysis. The viral titer was quantified using the LLC-MK2 plaque assay [8]. LLC-MK2 cells were seeded on a 6-well plate (BD Co.) at $2 \times 10^{5}$ cells/well and overlaid with $2.5 \mathrm{~mL}$ of M199 growth medium, penicillin $\mathrm{G}(100 \mathrm{U} / \mathrm{mL}), 0.5 \%$ agarose, $1 \%$ antibiotic-antimycotic solution, and $10 \%$ FBS. The cells in each well were infected with the diluted virus and incubated $\left(5 \% \mathrm{CO}_{2}\right.$ atmosphere, $\left.37^{\circ} \mathrm{C}, 4 \mathrm{~d}\right)$. After $4 \mathrm{~d}$, the cells and viruses were fixed using $3 \%$ formaldehyde (Thermo Fisher Scientific, Waltham, MA, USA) solution and stained with $0.05 \%$ crystal violet $(w / v$ in $10 \%$ ethanol) for plaque counting. The result was expressed as plaque-forming unit (PFU)/cube.

\subsection{Nitrate and Nitrite Contents}

Following the methods of Chou et al. [21] and Hsu et al. [22], high-performance liquid chromatography (HPLC, Agilent 110 series, Agilent Technologies, Santa Clara, CA, USA) was used to measure nitrate and nitrite concentrations. A mixture of $1 \mathrm{~g}$ of $\mathrm{CBC}$ and $50 \mathrm{~mL}$ of distilled water was heated in a water bath at $80^{\circ} \mathrm{C}$ for $20 \mathrm{~min}$. The heated solution was cooled down to room temperature, and filtered using a syringe filter (Dismic ${ }^{\circledR}-25 \mathrm{CP}$, cellulose acetate, pore size: $0.45 \mu \mathrm{m}$, Advance mfs, Inc., CA, USA) to prepare the sample for the analysis. The mobile phase of HPLC was $0.01 \mathrm{M}$ octylammonium orthophosphate in Methanol (30:70) $(v / v)$, and its flow rate was $0.8 \mathrm{~mL} / \mathrm{m}$. The column was a Symmetry ${ }^{\circledR} \mathrm{C} 18(5 \mu \mathrm{m}, 4.6 \mathrm{~mm} \times 250 \mathrm{~mm}$ I.D, Waters Co., MA, USA $)$ and the temperature of the column was maintained at $23 \pm 2^{\circ} \mathrm{C}$. Nitrate and nitrite were detected at $213 \mathrm{~nm}$ after injecting $10 \mu \mathrm{L}$ of the sample to a diode array detector (DAD, UV-Vis detector, G1315B, Agilent Technologies, Santa Clara, CA, USA). Sodium nitrate and sodium nitrite were used as reference materials for the standard curve.

\subsection{Experimental Animals}

Eight-week-old female and male SPF Sprague-Dawley rats were purchased from Orient Bio Inc. Throughout the experiment, five rats were placed in a polycarbonate breeder box $(240 \mathrm{~W} \times 390 \mathrm{~L} \times 175$ $\mathrm{H} \mathrm{mm}$ ) under the following conditions: temperature $23 \pm 3^{\circ} \mathrm{C}$; relative humidity $50 \pm 10 \%$; lighting duration 12 h (7 a.m. 7 p.m.); and light intensity 150-600 Lux. The rats were allowed access to liberal amounts of water and feed. An acute toxicity test, a subacute toxicity test, a blood biochemical test, and a hematological test were conducted according to the methods described by Han et al. [13].

\subsection{Acute and Subacute Toxicity}

The acute toxicity test involved two animal groups: A control group and an ADCP-treated group. The control group was orally administered phosphate buffer saline (PBS), while the ADCP-treated group was orally administered with $5000 \mathrm{mg} / \mathrm{kg}$ of ADCP-treated CBCs, once a day. Changes in hematological and pathological parameters were measured after $14 \mathrm{~d}$. Similarly, the subacute toxicity test involved control and ADCP-treated groups; the control group was orally administered with PBS, and the ADCP-treated group was orally administered with $1000 \mathrm{mg} / \mathrm{kg}$ of ADCP-treated CBCs, once 
a day, and hematological and pathological changes were measured after $14 \mathrm{~d}$. The CBCs that had not been treated with ADCP were excluded from the toxicity test, since chicken breast and WPI are commonly consumed foods and edible materials.

\subsection{Blood Biochemical and Hematological Tests}

A proportion of the blood collected from the abdominal aorta was used for the hematological test, while the rest was stored at $4{ }^{\circ} \mathrm{C}$ and centrifuged (3000 rpm, $20 \mathrm{~min}$ ), following which an automated biochemistry analyzer (Fuji Dry Chem 3500i, Fuji Photo Film Co., Osaka, Japan) was used to measure the following parameters: total glucose, blood urea nitrogen, creatine, total bilirubin, total protein, albumin, aspartate aminotransferase, alanine aminotransferase, triglyceride, total cholesterol, and high-density lipoprotein.

Blood collected for the hematological test was placed in a collecting bottle, containing the anticoagulant, EDTA-2K, following which an automated blood analyzer was used to measure the following parameters: white blood cells, red blood cells, hemoglobin, hematocrit, mean corpuscular volume, mean corpuscular hemoglobin, mean corpuscular hemoglobin concentration, and platelets.

\subsection{Storage Study}

To examine the changes in the growth of indigenous mesophilic bacteria, PET containers, each containing $15 \mathrm{ADCP}$-untreated or $15 \mathrm{ADCP}$-treated CBCs without Salmonella inoculation, were stored at $4{ }^{\circ} \mathrm{C}$ for $0,3,5,7,10,14$, and $21 \mathrm{~d}$, and at 14 and $24^{\circ} \mathrm{C}$ for $0,1,2,3$, and $5 \mathrm{~d}$. PET containers, each containing $15 \mathrm{ADCP}$-untreated or $15 \mathrm{ADCP}$-treated CBCs with Salmonella inoculation, were also stored at $4{ }^{\circ} \mathrm{C}$ for $0,3,5,7,10,14$, and $21 \mathrm{~d}$, and at $10^{\circ} \mathrm{C}$ for $0,3,5,7,10$, and $14 \mathrm{~d}$, to study the growth of Salmonella.

Changes in the $\mathrm{pH}$, color, total volatile basic nitrogen (TVBN), lipid oxidation, and tenderness of $\mathrm{CBC}$ s were determined during storage at $4{ }^{\circ} \mathrm{C}$ for $0,3,5,7,10,14$, and $21 \mathrm{~d}$, and at $24{ }^{\circ} \mathrm{C}$ for $0,1,2,3$, and $5 \mathrm{~d}$. Sensory properties were evaluated immediately after ADCP treatment and after storage for 3 $\mathrm{d}$ at $4{ }^{\circ} \mathrm{C}$. Samples used for temperature and humidity measurements during storage were prepared by placing CBCs together with a data logger (8829S, AZ Instrument Corp., Taichung City, Taiwan). Two such samples were prepared without $\mathrm{ADCP}$ treatment. The temperature during storage was $4.4 \pm 0.3$, $14.1 \pm 0.1$, and $23.9 \pm 0.2^{\circ} \mathrm{C}$, respectively, and relative humidity in the packaging container was $98.9 \pm$ $1.3,97.8 \pm 1.0$, and $95.4 \pm 1.4 \%$, at each temperature.

\subsection{1. $\mathrm{pH}$ and Color}

To measure $\mathrm{pH}$, one CBC ( $3.5 \mathrm{~g})$ and distilled water $(31.5 \mathrm{~g})$ were homogenized using a home processor (HR3556, Philips, Koninklijke Philips N.V., Amsterdam, The Netherlands) for $30 \mathrm{~s}$. The $\mathrm{pH}$ of the CBC solution was measured using a $\mathrm{pH}$ meter $(\mathrm{pH} / \mathrm{mV} /$ Temp meter Model PL-500, Duksan General Science, Seoul, Korea).

The color of CBC was measured via Illuminate D65 colorimeter (Minolta Chroma Meter CR-400, Minolta Camera Co., Osaka, Japan) and a $2^{\circ}$ standard observer. Colorimeter was calibrated using a white plate (Minolta calibration plate No.14233126, $Y=87.4, x=0.3174$, and $y=0.3353$ ). Three of the six sides of the $\mathrm{CBC}$ were measured.

\subsection{TVBN}

The TVBN of CBC was determined using a modified version of the Conway micro-diffusion method [23]. Ten grams of $C B C$ was mixed with $90 \mathrm{~mL}$ distilled water, and subjected to decompression filtration using Whatman No. 1 filter paper (Whatman Ltd., Kent, UK). One milliliter of the filtrate was placed in the outer chamber of the Conway unit, while $1 \mathrm{~mL}$ of $0.01 \mathrm{~N} \mathrm{H}_{3} \mathrm{BO}_{3}$ solution and $50 \mu \mathrm{L}$ of Conway reagent $(0.066 \%$ methyl red $+0.066 \%$ bromocresol green) were injected into the inner chamber. After greasing the Conway unit, $1 \mathrm{~mL}$ of $50 \% \mathrm{~K}_{2} \mathrm{CO}_{3}$ solution was injected into the outer chamber, which was completely sealed with a cap immediately. The Conway unit was vortexed horizontally and 
left to react at $37^{\circ} \mathrm{C}$ for $120 \mathrm{~min}$. After allowing it to stand, titration using $0.01 \mathrm{~N} \mathrm{H}_{2} \mathrm{SO}_{4}$ was carried out until the $\mathrm{H}_{3} \mathrm{BO}_{3}$ in the inner chamber turned light pink in color. The obtained values were fed to the following Equation (1) to calculate the TVBN.

$$
\operatorname{TVBN}(\mathrm{mg} \%)=0.14 \times(\mathrm{b}-\mathrm{a}) \times \mathrm{f} \times \mathrm{d} \times 100 / \mathrm{S}
$$

$\mathrm{b}=\mathrm{H}_{2} \mathrm{SO}_{4}(\mathrm{~mL}), \mathrm{a}=$ blank $(\mathrm{mL}), \mathrm{f}=0.01 \mathrm{~N} \mathrm{H}_{2} \mathrm{SO}_{4}$ factor, $\mathrm{d}=$ dilution factor and $\mathrm{S}=$ sample weight $(\mathrm{g})$.

\subsection{TBARS}

Estimation of the lipid oxidation of CBC was based on the TBARS content, according to Lund et al. [24]. One CBC (3.5 g), $10.5 \mathrm{~mL}$ of $7.5 \%$ trichloroacetic acid solution (Samchun Chemicals, Pyeongtaek, Korea) with $0.1 \%$ propylgallate (Sigma Aldrich) and $0.1 \%$ ethylenediamine tetraacetic acid, were homogenized at $5000 \mathrm{rpm}$ for $30 \mathrm{~s}$, using a hand-held homogenizer (Sujaenara, Bucheon, Korea). The homogenized solution was filtered through a filter paper (Whatman No. 1), following which $2 \mathrm{~mL}$ of filtrate and $2 \mathrm{~mL}$ of $0.02 \mathrm{M}$ thiobarbituric acid were mixed and heated in boiling water for $40 \mathrm{~min}$. Subsequently, the mixture was cooled on ice for $5 \mathrm{~min}$, and TBARS was measured at $530 \mathrm{~nm}$ using a spectrophotometer (X-ma 1000, Human Corp, Seoul, Korea). TBARS was expressed as mg malonaldehyde in $1 \mathrm{~kg}$ meat.

\subsection{Tenderness}

The tenderness of $\mathrm{CBC}$ was measured using the methods described by Barbanti and Pasquini [25]. A texture analyzer (TA-XT2; Stable Micro System Co., Ltd., Surrey, UK) equipped with a Warner-Bratzler blade (HDP/BS; Stable Micro Systems) was used to measure peak shear force (g). The test speed and cutting distances were $2.0 \mathrm{~mm} / \mathrm{s}$ and $100 \%$, respectively.

\subsection{Sensory Test}

The color, flavor, and appearance of $\mathrm{CBC}$ were evaluated. The sensory test was carried out after storing the ADCP-untreated and ADCP-treated CBCs at $4{ }^{\circ} \mathrm{C}$ for 0 and $3 \mathrm{~d}$. The panelists of the sensory test were women aged 20-29 at Seoul Women's University (Seoul, Korea). Prior to the test, the frequency of cooked chicken breast consumption by the panelists was investigated, and it was found that they consumed cooked chicken breast, including chicken salad, at least twice a month. A 9-point scale was applied where the 9-point evaluation was such that 1 indicated 'dislike extremely', 5 indicated 'moderate', and 9 indicated 'like extremely'. Thus, higher points indicated a stronger preference for a given property.

\subsection{Experimental Design and Statistical Analysis}

Experiments aimed at determining voltage and time of ADCP treatment were repeated four times, and for each round of the experiment, two packages containing CBCs were prepared for each treatment, and two CBCs from each package were randomly selected and analyzed. The storage study was repeated twice, and the number of CBCs used on the sampling day of storage for the measurement of indigenous mesophilic bacteria, Salmonella, and $\mathrm{pH}$, were four (two CBCs from each package of two ADCP-untreated packages or ADCP-treated packages); six (three CBCs from each package of two ADCP-untreated packages or ADCP-treated packages) for the measurements of color, TVBN, and lipid oxidation; and ten (five CBCs from each package of two ADCP-untreated packages or ADCP-treated packages) for tenderness measurement, after random selection. One analytical sample for each measurement was prepared from each CBC. CBCs were randomly chosen from packages assuming that the treatment inside a package was uniform, as indicated by the results of our preliminary studies, showing that microbial reduction, color, and tenderness of food samples after ADCP treatment were not influenced by the location of a sample inside a package $[16,20]$. In determining quality properties, each analytical sample was measured once for tenderness and thrice 
for other properties. Experimental data were analyzed using SPSS (Ver. 24, SPSS Inc., Chicago., IL, USA), where one-way analysis of variance (ANOVA) was applied, and Tukey's multiple range test was used as post-hoc analysis $(\alpha=0.05)$.

\section{Results and Discussion}

\subsection{Determination of ADCP Treatment Conditions}

To determine ADCP treatment conditions, Salmonella inactivation rate was evaluated under voltages of 22, 23, and $24 \mathrm{kV}$, for treatment times of 2.0, 2.5, and $3.0 \mathrm{~min}$ (Table 1). Increasing treatment voltage from $22 \mathrm{kV}$ to $24 \mathrm{kV}$ led to a significant increase in the Salmonella inactivation level $(p<$ $0.05)$, suggesting that treatment voltage is a critical variable in ADCP treatment for packaged meat products. Misra et al. reviewed studies that investigated the decontamination of foods and food simulants using different in-package cold plasma configurations. They concluded that increasing treatment time (plasma generation time) and voltage have a positive impact on reducing bacterial populations [7]. Increased efficacy of microbial inactivation may be associated with an increase in antimicrobial substances in the packages subjected to ADCP treatment. Wang et al. demonstrated that $\mathrm{ADCP}$ treatment of raw chicken fillet packaged in a polymeric tray at $80 \mathrm{kV}$ significantly increased the formation of ozone, a common component existing in packages treated with ADCP and a well-known antimicrobial agent, compared with $55 \mathrm{kV}$ at 200 to $950 \mathrm{rpm}$ [15].

Table 1. Effects of treatment voltage and time on the inactivation of Salmonella in chicken breast cubes by in-package atmospheric dielectric barrier discharge cold plasma (ADCP) treatment.

\begin{tabular}{|c|c|c|c|}
\hline \multicolumn{2}{|c|}{ Conditions } & \multirow{2}{*}{$\begin{array}{c}\text { Salmonella } \\
(\log \text { CFU/cube) }\end{array}$} & \multirow{2}{*}{$\begin{array}{l}\text { Microbial Reduction } \\
\text { (log CFU/cube) }\end{array}$} \\
\hline Treatment Voltage & Treatment Time & & \\
\hline $22 \mathrm{kV}$ & \multirow{2}{*}{$3 \mathrm{~min}$} & $4.42 \pm 0.05$ & $0.62 \pm 0.02^{c}$ \\
\hline $23 \mathrm{kV}$ & & $3.96 \pm 0.07$ & $1.08 \pm 0.03^{b}$ \\
\hline \multirow{3}{*}{$24 \mathrm{kV}$} & $2 \mathrm{~min}$ & $4.14 \pm 0.09$ & $0.90 \pm 0.07^{b}$ \\
\hline & $2.5 \mathrm{~min}$ & $4.04 \pm 0.13$ & $1.00 \pm 0.01^{b}$ \\
\hline & $3 \mathrm{~min}$ & $3.59 \pm 0.06$ & $1.45 \pm 0.05^{a}$ \\
\hline
\end{tabular}

The number of Salmonella in ADCP-untreated chicken breast cubes: $5.04 \pm 0.13$ log CFU/cube; values are meaning mean and standard deviations $(\mathrm{n}=4)$; different letters mean significant differences between data in the same column $(p<0.05)$.

Salmonella inactivation levels following ADCP treatment at $24 \mathrm{kV}$, for 2.0, 2.5 and $3.0 \mathrm{~min}$, were 0.90 $\pm 0.07,1.00 \pm 0.01$ and $1.45 \pm 0.05 \log \mathrm{CFU} /$ cube, respectively; treatment time of $3.0 \mathrm{~min}$ produced the highest inactivation level $(p<0.05)$. Moutiq et al. [1] reported that ADCP treatment at $100 \mathrm{kV}$ for 1,3 , and $5 \mathrm{~min}$ was applied to fresh chicken breast samples, where the highest inactivation (approximately $1.5 \log$ CFU/g reduction) in the natural microflora of chicken was achieved within 5 min of treatment and $24 \mathrm{~h}$ of storage [1]. Furthermore, they demonstrated that treatment time exerted a significant effect $(p<0.05)$ on the decrease in population for mesophiles, psychrotrophs, and Enterobacteriaceae [1]. Albertos et al. used dielectric barrier discharge cold plasma treatment on packaged fish samples in PET containers, and reported that increasing treatment time led to increased concentrations of antimicrobial ozone and nitrogen oxides $\left(\mathrm{NO}_{2}, \mathrm{NO}_{3}, \mathrm{~N}_{2} \mathrm{O}_{4}\right)$ [26]. The increase in Salmonella inactivation levels with treatment time suggests that treatment time was considered as another important variable affecting $\mathrm{ADCP}$ treatment. The treatment voltage of $24 \mathrm{kV}$ and $3 \mathrm{~min}$, which resulted in the highest Salmonella inactivation ( $1.45 \pm 0.05 \log \mathrm{CFU} / \mathrm{cube})$, were used for ADCP treatment in all subsequent experiments. Treatment times above 3.0 min were not investigated in this study because, in food production lines, post-packaging sterilization time is mostly limited to a few minutes [27]. 


\subsection{Effects on TV Inactivation}

The inactivation effect exerted by ADCP treatment on TV in CBCs at $24 \mathrm{kV}$ for 3 min was evaluated, and the reduction of TV in ADCP-treated CBCs was $1.08 \pm 0.15 \log$ PFU/cube (Table 2). Substantiating the above results, Min at al. showed that TV on lettuce was reduced by $1.3 \pm 0.2 \mathrm{log} \mathrm{PFU} / \mathrm{g}$ following ADCP treatment at $34.8 \mathrm{kV}$ for $5 \mathrm{~min}$ [9]. Lacombe et al. exhibited that TV on blueberries was inactivated by $1.5 \mathrm{PFU} / \mathrm{g}$ after atmospheric plasma jet treatment for $45 \mathrm{~s}$ [18]. Bae et al. reported that atmospheric pressure plasma jet treatment on fresh beef loin, fresh chicken breast, and fresh pork shoulder produced 2.05, 2.01, and $2.11 \mathrm{log}$ PFU/mL reductions of Murine norovirus, respectively [28]. Reactive species and UV photons generated during ADCP treatment reportedly destroy the polypeptide chain of the viral capsid, while inhibiting protein biosynthesis by reacting with viral RNA encoding surface, capsid, maturation, and lysis proteins, as well as replicase protein $[8,18,29-31]$. Hence, the findings of this study, which indicate that TV is a surrogate of human norovirus, suggests that ADCP is effective in inactivating human norovirus that may infect in RTE-type chicken meat products.

Table 2. Effects of in-package atmospheric dielectric barrier discharge cold plasma (ADCP) treatment on the inactivation of Salmonella, natural mesophilic aerobic bacteria, and Tulane virus, and the concentrations of nitrite, and nitrate in chicken breast cubes.

\begin{tabular}{ccc}
\hline Microorganisms and Nitrite/Nitrate Concentrations & Untreated & ADCP-Treated \\
\hline Salmonella $(\mathrm{CFU} / \mathrm{cube})$ & $5.04 \pm 0.13^{\mathrm{a}}$ & $3.59 \pm 0.06^{\mathrm{b}}$ \\
Indigenous mesophilic bacteria (CFU/cube) & $5.78 \pm 0.19^{\mathrm{a}}$ & $5.08 \pm 0.16^{\mathrm{b}}$ \\
Tulane virus (PFU/cube) & $3.68 \pm 0.29^{\mathrm{a}}$ & $2.60 \pm 0.34^{\mathrm{b}}$ \\
Nitrite $(\mu \mathrm{g} / \mathrm{mL})$ & $6.31 \pm 0.21^{\mathrm{b}}$ & $9.31 \pm 0.20^{\mathrm{a}}$ \\
Nitrate $(\mu \mathrm{g} / \mathrm{mL})$ & $1.51 \pm 0.13^{\mathrm{a}}$ & $1.40 \pm 0.07^{\mathrm{a}}$ \\
\hline
\end{tabular}

The ADCP treatment voltage and time were $24 \mathrm{kV}$ and $3 \mathrm{~min}$, respectively; values are meaning mean and standard deviations $(\mathrm{n}=4)$; different letters mean significant differences between data in the same row $(p<0.05)$.

\subsection{Effects on Nitrite and Nitrate Contents}

Cold plasma is an effective source of reactive oxygen and nitrogen species (RONS) [32]. Potential accumulation of nitrites and nitrates in plasma-treated foods may affect food safety. Thus, nitrite and nitrate concentrations in plasma-treated food products should be monitored to ensure acceptable levels [32-34]. To evaluate the production of nitrate and nitrite following ADCP treatment, changes in their contents before and after ADCP treatment were examined. Nitrate content before and after ADCP treatment showed an increase from $6.31 \pm 0.21$ to $9.31 \pm 0.20 \mu \mathrm{g} / \mathrm{mL}(p<0.05)$, whereas nitrite content changed from $1.51 \pm 0.13$ to $1.40 \pm 0.07 \mu \mathrm{g} / \mathrm{mL}$ without a significant difference (Table 2). Nitrate may be produced via oxidation of nitrite, and the increase of nitrate in this study is thought to be due to nitrite oxidation induced by the reactive species generated during cold plasma treatment $[35,36]$. Jung et al. reported that nitrite in meat batter increased according to the duration of atmospheric pressure plasma treatment [33]. Yong et al. also reported an increase in nitrite when dielectric barrier discharge plasma treatment was applied to pork jerky [34]. According to Oehmigen et al., nitrite produced during cold plasma treatment may lower the $\mathrm{pH}$ of liquids [37]. In this study, however, there was no significant difference between nitrite levels before and after ADCP treatment, while the $\mathrm{pH}$ of CBCs immediately following the treatment did not show a significant difference either. Thus, these results suggest that nitrite and nitrate contents would not pose a safety threat for CBCs. 


\subsection{Effects on Toxicity}

Atmospheric cold plasma may affect the chemical and nutritional properties of food. Thus, a proper risk assessment of ADCP treatment needs to be performed to ensure food safety [13]. To investigate the toxicological safety of ADCP treatment, acute and subacute toxicity tests were conducted with respect to hematological and blood biochemical parameters. No deaths or clinical signs related to local or systemic toxic effects were observed during and after acute and subacute exposure periods. ADCP-treated CBCs did not show a significant difference in terms of changes in weight gain of Sprague-Dawley rats and food intake, compared to the control (Table $3 ; p>0.05$ ). The evaluation of hematological parameters using whole blood (Table 3) found no significant difference across all parameters between the control and ADCP-treated CBCs $(p>0.05)$, and an identical pattern was observed in both acute and subacute tests. The hematopoietic system is generally the most sensitive target of toxic substances, and thus, it is an important parameter in evaluating human and animal physiological and pathological statuses [38]. These results demonstrated that ADCP-treated CBCs were essentially nontoxic, suggesting that $\mathrm{ADCP}$ treatment does not generate harmful by-products in CBCs.

The changes in serum following oral administering to experimental samples, are presented (Table 4). Biochemical parameters of blood, which were used in this study, included certain enzymes and protein levels. Aspartate aminotransferase, alanine aminotransferase, and total bilirubin act as indicators of hepatocellular damage, while the levels of blood urea nitrogen and creatine act as biomarkers of nephrotoxicity [39]. Acute toxicity tests indicated that all blood biochemical parameters showed no significant difference between female rats administered ADCP-treated CBCs and the control $(p>0.05)$, except that blood urea nitrogen and triglyceride levels for ADCP-treated CBCs were slightly lower than that of the control. In addition, no significant differences were observed between parameters of ADCP-treated CBCs of male rats and those of the control $(p>0.05)$, except for the levels of total protein and albumin. However, changes in total protein and albumin values were surmised to be toxicologically irrelevant, because the values remained within physiologically normal ranges, despite statistical differences. Similarly, subacute toxicity tests indicated that there were no significant differences between the parameters of $\mathrm{ADCP}$-treated $\mathrm{CBCs}$ of male and female rats and those of the controls $(p>0.05)$, except for the levels of total bilirubin in female rats and the levels of total bilirubin and total protein in male rats. Furthermore, because changes in the values of total bilirubin and total protein were physiologically within normal ranges despite statistical differences, these changes were considered as toxicologically irrelevant. Similarly, Han et al. reported that, according to the toxicity tests assessing microwave cold plasma treatment of edible defatted soybean meal-based film, the clinical differences between hematological and blood biochemical parameters were not significantly different as their levels were within normal physiological ranges, although changes were observed in the levels of some components (hemoglobin and hematocrit in hematological parameters and total bilirubin, aspartate aminotransferase, and creatinine in biochemical parameters) [13]. 
Table 3. Bodyweight gain, daily food intake, and hematological parameters of Sprague-Dawley rats following oral administration of chicken breast cubes with and without in-package atmospheric dielectric barrier discharge cold plasma (ADCP) treatment to assess acute and subacute toxicity.

\begin{tabular}{|c|c|c|c|c|c|c|}
\hline & \multirow{2}{*}{ Parameter } & & \multicolumn{2}{|c|}{ Group for Acute Toxicity } & \multicolumn{2}{|c|}{ Group for Subacute Toxicity } \\
\hline & & & Control & ADCP-Treated & Control & ADCP-Treated \\
\hline \multirow{6}{*}{$\begin{array}{l}\text { Bodyweight gain } \\
\text { and daily intake }\end{array}$} & \multirow{3}{*}{ Female } & Bodyweight gain (g) & $57.20 \pm 5.70$ & $59.50 \pm 3.53$ & $64.20 \pm 5.98^{a}$ & $46.00 \pm 2.13^{b}$ \\
\hline & & Food intake (g/day) & $22.20 \pm 0.82$ & $22.02 \pm 1.87$ & $24.09 \pm 1.06$ & $21.73 \pm 0.21$ \\
\hline & & Water intake (mL/day) & $23.48 \pm 0.33$ & $25.12 \pm 0.04$ & $24.04 \pm 1.09$ & $27.36 \pm 2.30$ \\
\hline & \multirow{3}{*}{ Male } & Bodyweight gain (g) & $133.70 \pm 4.06$ & $111.50 \pm 1.55$ & $122.50 \pm 4.84^{\mathrm{a}}$ & $93.60 \pm 5.63^{b}$ \\
\hline & & Food intake (g/day) & $29.01 \pm 1.98$ & $28.38 \pm 1.54$ & $28.42 \pm 1.03$ & $24.56 \pm 0.73$ \\
\hline & & Water intake (mL/day) & $29.28 \pm 1.23$ & $28.46 \pm 0.10$ & $32.70 \pm 0.75$ & $26.79 \pm 0.04$ \\
\hline \multirow{16}{*}{$\begin{array}{l}\text { Hematological } \\
\text { parameters }\end{array}$} & \multirow{8}{*}{ Female } & $\mathrm{RBC}\left(\times 10^{6} / \mu \mathrm{L}\right)$ & $7.47 \pm 0.33$ & $7.53 \pm 0.29$ & $7.47 \pm 0.19^{b}$ & $7.76 \pm 0.16^{\mathrm{a}, \mathrm{b}}$ \\
\hline & & $\mathrm{WBC}\left(\times 10^{3} / \mu \mathrm{L}\right)$ & $7.29 \pm 0.69^{a, b}$ & $10.19 \pm 1.14^{\mathrm{a}, \mathrm{b}}$ & $7.29 \pm 0.40$ & $8.36 \pm 0.85$ \\
\hline & & Hct $(\%)$ & $58.98 \pm 2.62$ & $58.23 \pm 1.28$ & $58.98 \pm 1.51^{\mathrm{a}, \mathrm{b}}$ & $59.16 \pm 0.73^{b}$ \\
\hline & & $\mathrm{Hgb}(\mathrm{g} / \mathrm{dL})$ & $15.73 \pm 0.66$ & $15.25 \pm 0.38$ & $15.73 \pm 0.38^{b}$ & $16.04 \pm 0.26^{\mathrm{a}, \mathrm{b}}$ \\
\hline & & $\mathrm{MCV}(\mathrm{fL})$ & $78.88 \pm 0.28$ & $77.53 \pm 1.26$ & $78.88 \pm 0.16^{\mathrm{a}}$ & $76.28 \pm 0.91^{b}$ \\
\hline & & $\mathrm{MCH}(\mathrm{pg})$ & $21.05 \pm 0.21$ & $20.33 \pm 0.36$ & $21.05 \pm 0.12$ & $20.66 \pm 0.25$ \\
\hline & & $\mathrm{MCHC}(\mathrm{g} / \mathrm{dL})$ & $26.68 \pm 0.30$ & $26.23 \pm 0.18$ & $26.68 \pm 0.17^{b, c}$ & $27.12 \pm 0.34^{\mathrm{a}}$ \\
\hline & & Platelets $\left(\times 10^{3} / \mu \mathrm{L}\right)$ & $1476.75 \pm 216.80$ & $1349.75 \pm 153.03$ & $1476.75 \pm 125.17$ & $1390.80 \pm 119.25$ \\
\hline & \multirow{8}{*}{ Male } & $\mathrm{RBC}\left(\times 10^{6} / \mu \mathrm{L}\right)$ & $7.47 \pm 0.27$ & $7.13 \pm 0.25$ & $7.28 \pm 0.31^{\mathrm{a}, \mathrm{b}}$ & $7.30 \pm 0.75^{\mathrm{a}, \mathrm{b}}$ \\
\hline & & $\mathrm{WBC}\left(\times 10^{3} / \mu \mathrm{L}\right)$ & $8.96 \pm 0.98$ & $8.94 \pm 0.96$ & $8.71 \pm 0.78$ & $7.40 \pm 0.37$ \\
\hline & & Hct $(\%)$ & $62.00 \pm 1.85$ & $60.00 \pm 1.95$ & $60.35 \pm 1.33^{a, b}$ & $60.30 \pm 4.40^{\mathrm{a}, \mathrm{b}}$ \\
\hline & & $\mathrm{Hgb}(\mathrm{g} / \mathrm{dL})$ & $15.66 \pm 0.47$ & $15.05 \pm 0.46$ & $15.28 \pm 0.33$ & $13.95 \pm 2.35$ \\
\hline & & $\mathrm{MCV}(\mathrm{fL})$ & $83.08 \pm 1.03$ & $84.13 \pm 0.65$ & $83.13 \pm 1.83$ & $82.95 \pm 2.45$ \\
\hline & & $\mathrm{MCH}(\mathrm{pg})$ & $20.96 \pm 0.25$ & $21.10 \pm 0.18$ & $21.00 \pm 0.45^{\mathrm{a}}$ & $19.05 \pm 1.25^{b}$ \\
\hline & & $\mathrm{MCHC}(\mathrm{g} / \mathrm{dL})$ & $25.24 \pm 0.08$ & $25.08 \pm 0.19$ & $25.28 \pm 0.06$ & $23.00 \pm 2.20$ \\
\hline & & Platelets $\left(\times 10^{3} / \mu \mathrm{L}\right)$ & $1600.60 \pm 170.63$ & $1877.50 \pm 339.03$ & $1805.75 \pm 120.68$ & $1197.00 \pm 286.00$ \\
\hline
\end{tabular}


Table 4. Blood biochemical parameters and relative organ weights of Sprague-Dawley rats following oral administration of chicken breast cubes with and without in-package atmospheric dielectric barrier discharge cold plasma (ADCP) treatment to assess acute and subacute toxicity.

\begin{tabular}{|c|c|c|c|c|c|c|}
\hline & \multirow{2}{*}{ Parameters } & & \multicolumn{2}{|c|}{ Group for Acute Toxicity } & \multicolumn{2}{|c|}{ Group for Subacute Toxicity } \\
\hline & & & Control & ADCP-Treated & Control & ADCP-Treated \\
\hline \multirow{22}{*}{$\begin{array}{l}\text { Blood biochemical } \\
\text { parameters }\end{array}$} & \multirow{11}{*}{ Female } & Glucose $(\mathrm{mg} / \mathrm{dL})$ & $108.20 \pm 16.60$ & $77.40 \pm 6.42$ & $90.60 \pm 10.73$ & $90.00 \pm 7.48$ \\
\hline & & $\mathrm{BUN}(\mathrm{mg} / \mathrm{dL})$ & $18.30 \pm 0.41^{\mathrm{a}}$ & $16.10 \pm 0.92^{a, b}$ & $13.82 \pm 0.59$ & $13.56 \pm 1.11$ \\
\hline & & Creatinine (mg/dL) & $0.20 \pm 0.00$ & $0.18 \pm 0.02$ & $0.20 \pm 0.00$ & $0.20 \pm 0.00$ \\
\hline & & Total bilirubin (mg/dL) & $0.54 \pm 0.02$ & $0.58 \pm 0.04$ & $0.58 \pm 0.02^{\mathrm{a}}$ & $0.42 \pm 0.04^{b}$ \\
\hline & & Total protein $(\mathrm{g} / \mathrm{dL})$ & $6.46 \pm 0.14$ & $6.62 \pm 0.27$ & $6.26 \pm 0.18$ & $6.26 \pm 0.08$ \\
\hline & & Albumin $(\mathrm{g} / \mathrm{dL})$ & $4.76 \pm 0.28$ & $5.14 \pm 0.27$ & $4.74 \pm 0.21$ & $4.56 \pm 0.07$ \\
\hline & & AST $(\mathrm{U} / \mathrm{L})$ & $72.20 \pm 3.61$ & $70.20 \pm 2.80$ & $70.00 \pm 1.45$ & $69.60 \pm 0.87$ \\
\hline & & ALT $(\mathrm{U} / \mathrm{L})$ & $80.80 \pm 9.98$ & $31.60 \pm 2.79$ & $25.40 \pm 0.93$ & $26.80 \pm 1.24$ \\
\hline & & Triglyceride (mg/dL) & $80.80 \pm 9.98^{\mathrm{a}}$ & $61.20 \pm 12.13^{a, b}$ & $63.00 \pm 6.29$ & $77.20 \pm 5.21$ \\
\hline & & Total cholesterol (mg/dL) & $103.40 \pm 5.68$ & $87.60 \pm 6.59$ & $102.00 \pm 10.90$ & $97.40 \pm 6.77$ \\
\hline & & HDL $(\mathrm{mg} / \mathrm{dL})$ & $60.8 \pm 4.75$ & $53.60 \pm 3.11$ & $59.60 \pm 7.61$ & $63.20 \pm 4.68$ \\
\hline & \multirow{11}{*}{ Male } & Glucose $(\mathrm{mg} / \mathrm{dL})$ & $81.60 \pm 9.26$ & $141.20 \pm 21.69$ & $100.40 \pm 20.86$ & $87.20 \pm 7.10$ \\
\hline & & BUN (mg/dL) & $12.14 \pm 0.43$ & $14.28 \pm 1.40$ & $11.86 \pm 0.69$ & $12.36 \pm 0.66$ \\
\hline & & Creatinine (mg/dL) & $0.24 \pm 0.02$ & $0.16 \pm 0.04$ & $0.20 \pm 0.03$ & $0.20 \pm 0.00$ \\
\hline & & Total bilirubin (mg/dL) & $0.52 \pm 0.04$ & $0.56 \pm 0.02$ & $4.48 \pm 0.11^{\mathrm{b}}$ & $5.74 \pm 0.27^{\mathrm{a}}$ \\
\hline & & Total protein $(\mathrm{g} / \mathrm{dL})$ & $6.10 \pm 0.07^{b}$ & $6.66 \pm 0.13^{a}$ & $5.92 \pm 0.13^{a}$ & $4.46 \pm 0.39^{b}$ \\
\hline & & Albumin $(\mathrm{g} / \mathrm{dL})$ & $4.54 \pm 0.10^{b}$ & $5.06 \pm 0.12^{a}$ & $0.38 \pm 0.04$ & $0.50 \pm 0.10$ \\
\hline & & AST $(\mathrm{U} / \mathrm{L})$ & $75.20 \pm 2.06$ & $82.00 \pm 4.88$ & $80.20 \pm 4.12$ & $78.60 \pm 2.62$ \\
\hline & & $\operatorname{ALT}(\mathrm{U} / \mathrm{L})$ & $39.80 \pm 3.89$ & $41.20 \pm 1.69$ & $32.60 \pm 2.46$ & $33.80 \pm 1.98$ \\
\hline & & Triglyceride (mg/dL) & $123.20 \pm 5.70$ & $89.60 \pm 9.94$ & $104.20 \pm 8.13$ & $80.00 \pm 2.68$ \\
\hline & & Total cholesterol (mg/dL) & $114.80 \pm 11.75$ & $108.60 \pm 7.58$ & $100.00 \pm 3.52$ & $103.00 \pm 7.31$ \\
\hline & & HDL $(\mathrm{mg} / \mathrm{dL})$ & $68.00 \pm 3.74$ & $57.20 \pm 4.29$ & $55.60 \pm 3.08$ & $55.20 \pm 4.00$ \\
\hline \multirow{10}{*}{$\begin{array}{l}\text { Relative organ weight } \\
\text { (g/100 g of bodyweight) }\end{array}$} & \multirow{5}{*}{ Female } & Liver & $3.65 \pm 0.14$ & $3.61 \pm 0.24$ & $3.60 \pm 0.08$ & $3.68 \pm 0.06$ \\
\hline & & Kidney & $0.92 \pm 0.02$ & $0.96 \pm 0.03$ & $0.94 \pm 0.02$ & $1.02 \pm 0.05$ \\
\hline & & Lung & $0.87 \pm 0.18$ & $0.71 \pm 0.08$ & $0.71 \pm 0.06$ & $0.72 \pm 0.04$ \\
\hline & & Heart & $0.57 \pm 0.11$ & $0.48 \pm 0.03$ & $0.51 \pm 0.03$ & $0.50 \pm 0.01$ \\
\hline & & Spleen & $0.24 \pm 0.02$ & $0.25 \pm 0.01$ & $0.24 \pm 0.02$ & $0.25 \pm 0.01$ \\
\hline & \multirow{5}{*}{ Male } & Liver & $3.47 \pm 0.10$ & $3.24 \pm 0.21$ & $3.56 \pm 0.11$ & $3.44 \pm 0.15$ \\
\hline & & Kidney & $0.86 \pm 0.03$ & $0.79 \pm 0.02$ & $1.00 \pm 0.02$ & $0.99 \pm 0.03$ \\
\hline & & Lung & $0.66 \pm 0.06$ & $0.56 \pm 0.05$ & $0.81 \pm 0.19$ & $0.62 \pm 0.07$ \\
\hline & & Heart & $0.48 \pm 0.06$ & $0.46 \pm 0.03$ & $0.49 \pm 0.02$ & $0.46 \pm 0.03$ \\
\hline & & Spleen & $0.25 \pm 0.01$ & $0.26 \pm 0.01$ & $0.23 \pm 0.00$ & $0.28 \pm 0.02$ \\
\hline
\end{tabular}

Values represent the mean \pm SE of five rats per group. In the acute toxicity test, the control group and the ADCP-treated group were orally administered a single dose of PBS and $5000 \mathrm{mg} / \mathrm{kg}$ of ADCP-treated CBCs, respectively, in a water vehicle, with no further treatment for $14 \mathrm{~d}$. In the subacute toxicity test, the control group and the ADCP-treated group were orally administered PBS and $1000 \mathrm{mg} / \mathrm{kg} / \mathrm{d}$ of ADCP-treated CBCs, respectively, in a water vehicle for $14 \mathrm{~d}$. Differences between the control and samples (ADCP-treated) animals in acute or subacute toxicity treatment groups were evaluated using one-way ANOVA and Tukey's multiple range tests. Different superscripts indicate significant differences among groups $(p<0.05)$. 
In general, weight loss in an internal organ is a sensitive index of toxicity [40]. Both acute and subacute toxicity analyses of weight changes in organs following the oral administering of ADCP-treated CBCs (Table 4) showed that there were no significant differences between weight changes in the livers, kidneys, lungs, hearts, and spleens of ADCP-treated CBCs and those of the control, and similarly, that there was no significant difference between male and female groups concerning these changes. Thus, it is thought that ADCP-treated CBCs did not cause internal organ damage, suggesting that these are essentially nontoxic.

The global regulatory approaches for applying new technologies to food products are diverse. For example, in the EU, plasma-treated food products must obtain the European Commission's Food Safety approval. The first step requires 'a scientific assessment prior to authorization to ensure their safety' through the European Food Safety Authority (EFSA). Currently, uncertainty remains in the European Commission regulatory approval process for atmospheric cold plasma, due to the lack of definition within the evaluation criteria, including the 'risk to public health' [32]. Further research to obtain data regarding technologies evaluating the toxicological safety of cold plasma-treated food products is warranted.

\subsection{Effect on Post-Treatment Storage}

\subsubsection{Changes in Microbial Growth}

To evaluate the effect of ADCP treatment on storage quality of $\mathrm{CBCs}$, the changes in microbial growth, as well as in $\mathrm{pH}$, color, TVBN, TBARS, tenderness, and sensory properties, during the storage of $\mathrm{CBC}$ s following ADCP treatment, were analyzed.

Changes in the growth of indigenous mesophilic bacteria and Salmonella in CBCs during storage following ADCP treatment were evaluated (Figure 1). The initial population of indigenous mesophilic bacteria on CBCs, $5.78 \pm 0.19 \log \mathrm{CFU} / \mathrm{cube}$, decreased to $5.08 \pm 0.16 \log \mathrm{CFU} / \mathrm{cube}$ following ADCP treatment (Figure 1A). ADCP-treated CBCs, stored at $4{ }^{\circ} \mathrm{C}$ for $21 \mathrm{~d}$, showed a steady microbial growth inhibition leading to a reduction of $0.7-0.9 \log \mathrm{CFU} / \mathrm{cube}$. Post-treatment storage reportedly enhances the microbial inactivation efficacy of $\mathrm{ADCP}$, due to cold plasma reactive species within closed containers diffusing into product tissues during storage [41]. However, microbial growth or inhibition rates in $\mathrm{CBC}$ with and without ADCP treatment appeared to be similar at both 4 and $10^{\circ} \mathrm{C}$. This may be due to the non-hermetic sealing of the commercial PET containers used in this study, whereby the reactive species generated during ADCP treatment were lost to the exterior of the container. Thus, it is anticipated that future packaging would involve hermetic sealing of in-package ADCP-treated food, in order to ensure more substantial inactivation of microbial growth during storage.

No significant difference was observed between the populations of ADCP treated indigenous bacteria, stored at 14 and $24{ }^{\circ} \mathrm{C}$ for $5 \mathrm{~d}$ and $1 \mathrm{~d}(p>0.05)$. This verified that storage at refrigeration temperatures exerts an effective inhibitory effect on the growth of indigenous mesophilic bacteria on RTE chicken meat. 
(A)

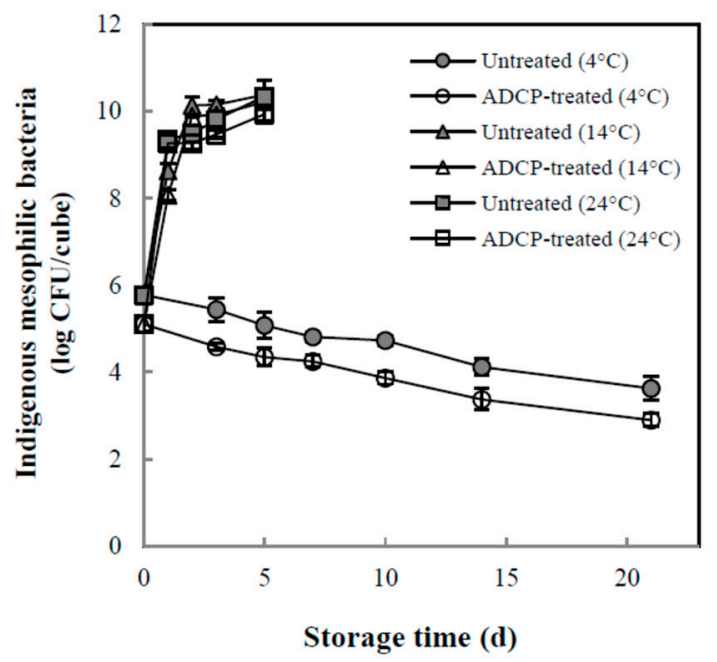

(B)

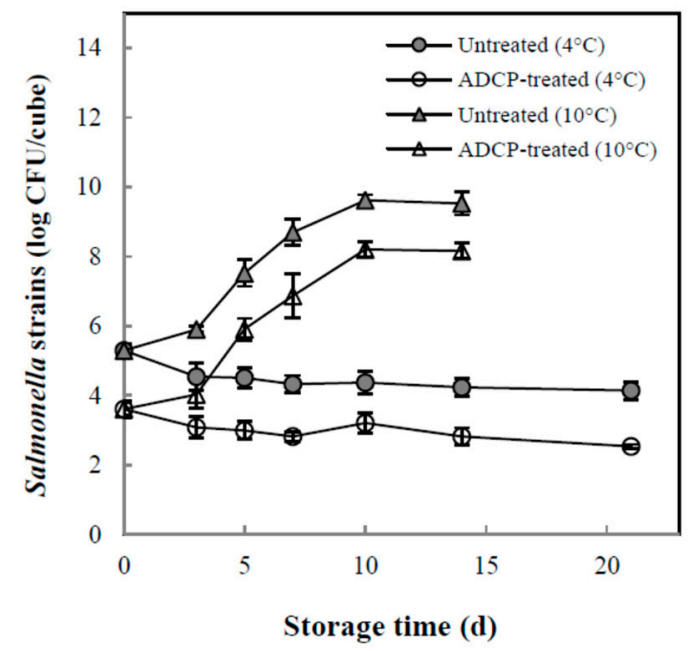

Figure 1. Effects of atmospheric dielectric barrier discharge cold plasma treatment (ADCP) treatment on the growth of total indigenous mesophilic aerobic microorganism on chicken breast cubes (CBCs) during storage at 4,14 , and $24{ }^{\circ} \mathrm{C}(\mathbf{A})$ and Salmonella strains on $\mathrm{CBC}$ during storage at 4 and $10{ }^{\circ} \mathrm{C}(\mathbf{B})$.

Salmonella inoculated into CBCs were reduced by $1.45 \pm 0.05 \log$ CFU/cube, from $5.04 \pm 0.13$ $\log \mathrm{CFU} / \mathrm{cube}$ to $3.59 \pm 0.06 \log \mathrm{CFU} / \mathrm{cube}$, due to ADCP treatment (Figure 1B). The microbial level of ADCP-treated CBCs stored at $4{ }^{\circ} \mathrm{C}$ for $21 \mathrm{~d}$ were reduced by 1.4-1.7 $\log \mathrm{CFU} / \mathrm{cube}$ (which was maintained), compared to untreated CBCs. However, as a similar result was also observed for indigenous mesophilic bacteria, the sublethal injury could not be ascertained. Storage at $10^{\circ} \mathrm{C}$ for $14 \mathrm{~d}$ resulted in microbial levels being reduced by 1.3-1.7 log CFU/cube, where a steady increase in which reduction was maintained, and similarly, the sublethal injury could not be ascertained.

\subsection{2. $\mathrm{pH}$ and Color}

The $\mathrm{pH}$ and color of ADCP treated $\mathrm{CBC}$ s during storage are presented (Table 5). Depending on the $\mathrm{ADCP}$ treatment, the $\mathrm{pH}$ of $\mathrm{CBC}$ s stored at $4{ }^{\circ} \mathrm{C}$ and $24{ }^{\circ} \mathrm{C}$, remained within the $6.5-6.6$ range, results did not have significant differences among themselves $(p>0.05)$, indicating that ADCP treatment had not influenced the $\mathrm{pH}$ of $\mathrm{CBC}$. Reactive species generated during cold plasma treatment may react with food surface moisture to produce acidic compounds, which may cause changes in the $\mathrm{pH}$ [42]. As seen in the previous investigation of nitrate and nitrite contents, nitrogen species generated during cold plasma treatment may induce the formation of nitric acid leading to a consequent decrease in $\mathrm{pH}$ [37]. However, it is likely that the number of nitrogen species generated in this study were insufficient, as several studies have reported that cold plasma treatment did not alter the $\mathrm{pH}$ of meat $[43,44]$. The CBCs used in this study had been given the WPI coating, and based on the characteristically short penetration depth of cold plasma (e.g., $\leq 10 \mathrm{~nm}, 1 \mu \mathrm{m}$ ) [45,46], it is thought that the reaction was with the WPI coating on the surface of CBCs and was not substantial to change the bulk $\mathrm{pH}$. 
Table 5. Effects of atmospheric dielectric barrier discharge cold plasma (ADCP) treatment on the $\mathrm{pH}$ and color of chicken breast cubes during storage at 4 and $24{ }^{\circ} \mathrm{C}$.

\begin{tabular}{|c|c|c|c|c|c|c|c|c|c|}
\hline \multirow{3}{*}{$\begin{array}{c}\text { Storage } \\
\text { Temperature } \\
\left({ }^{\circ} \mathrm{C}\right)\end{array}$} & \multirow{3}{*}{$\begin{array}{l}\text { Storage Time } \\
\text { (d) }\end{array}$} & \multirow{2}{*}{\multicolumn{2}{|c|}{$\mathrm{pH}$}} & \multicolumn{6}{|c|}{ Color } \\
\hline & & & & \multicolumn{2}{|c|}{$L^{*}$} & \multicolumn{2}{|c|}{$a^{*}$} & \multicolumn{2}{|c|}{$b^{*}$} \\
\hline & & Untreated & ADCP-Treated & Untreated & ADCP-Treated & Untreated & ADCP-Treated & Untreated & ADCP-Treated \\
\hline \multirow{7}{*}{4} & 0 & $6.6 \pm 0.1^{\mathrm{A}, \mathrm{a}}$ & $6.5 \pm 0.0^{\mathrm{A}, \mathrm{a}}$ & $81.1 \pm 1.1^{\mathrm{A}, \mathrm{a}}$ & $81.0 \pm 1.1 \mathrm{~A}, \mathrm{a}$ & $2.2 \pm 0.6^{\mathrm{A}, \mathrm{a}}$ & $2.1 \pm 0.4^{\mathrm{A}, \mathrm{a}}$ & $15.5 \pm 0.8^{\mathrm{A}, \mathrm{a}}$ & $15.3 \pm 0.7^{\mathrm{A}, \mathrm{a}}$ \\
\hline & 3 & $6.5 \pm 0.1 \mathrm{~A}, \mathrm{a}$ & $6.6 \pm 0.1^{\mathrm{A}, \mathrm{a}}$ & $80.8 \pm 1.0^{\mathrm{A}, \mathrm{a}}$ & $80.8 \pm 0.9^{\mathrm{A}, \mathrm{a}}$ & $1.5 \pm 0.3^{\mathrm{A}, \mathrm{b}}$ & $1.4 \pm 0.3^{\mathrm{A}, \mathrm{b}}$ & $15.3 \pm 0.8^{\mathrm{A}, \mathrm{a}}$ & $15.5 \pm 0.7^{\mathrm{A}, \mathrm{a}}$ \\
\hline & 5 & $6.5 \pm 0.1 \mathrm{~A}, \mathrm{a}$ & $6.6 \pm 0.1^{\mathrm{A}, \mathrm{a}}$ & $80.6 \pm 1.1^{\mathrm{A}, \mathrm{a}}$ & $80.8 \pm 0.9^{\mathrm{A}, \mathrm{a}}$ & $1.0 \pm 0.4^{\mathrm{A}, \mathrm{c}}$ & $1.0 \pm 0.4^{\mathrm{A}, \mathrm{c}}$ & $15.2 \pm 1.0^{\mathrm{A}, \mathrm{a}}$ & $15.3 \pm 0.8^{\mathrm{A}, \mathrm{a}}$ \\
\hline & 7 & $6.5 \pm 0.1 \mathrm{~A}, \mathrm{a}$ & $6.5 \pm 0.1^{\mathrm{A}, \mathrm{a}}$ & $80.9 \pm 0.9^{\mathrm{A}, \mathrm{a}}$ & $81.1 \pm 1.1^{\mathrm{A}, \mathrm{a}}$ & $0.6 \pm 0.3^{\mathrm{A}, \mathrm{d}}$ & $0.7 \pm 0.3^{\mathrm{A}, \mathrm{d}}$ & $15.4 \pm 0.7^{\mathrm{A}, \mathrm{a}}$ & $15.4 \pm 0.7^{\mathrm{A}, \mathrm{a}}$ \\
\hline & 10 & $6.6 \pm 0.1^{\mathrm{A}, \mathrm{a}}$ & $6.6 \pm 0.1^{\mathrm{A}, \mathrm{a}}$ & $80.9 \pm 1.1^{\mathrm{A}, \mathrm{a}}$ & $81.1 \pm 1.2^{\mathrm{A}, \mathrm{a}}$ & $0.4 \pm 0.3^{\mathrm{A}, \mathrm{de}}$ & $0.5 \pm 0.2^{\mathrm{A}, \mathrm{de}}$ & $15.2 \pm 1.1^{\mathrm{A}, \mathrm{a}}$ & $15.0 \pm 0.7^{\mathrm{A}, \mathrm{a}}$ \\
\hline & 14 & $6.5 \pm 0.1 \mathrm{~A}, \mathrm{a}$ & $6.6 \pm 0.1^{\mathrm{A}, \mathrm{a}}$ & $81.1 \pm 0.8^{\mathrm{A}, \mathrm{a}}$ & $81.3 \pm 1.0^{\mathrm{A}, \mathrm{a}}$ & $0.2 \pm 0.3^{\mathrm{A}, \mathrm{ef}}$ & $0.2 \pm 0.2^{\mathrm{A}, \mathrm{ef}}$ & $15.4 \pm 0.8^{\mathrm{A}, \mathrm{a}}$ & $15.3 \pm 0.9^{\mathrm{A}, \mathrm{a}}$ \\
\hline & 21 & $6.6 \pm 0.1^{\mathrm{A}, \mathrm{a}}$ & $6.6 \pm 0.1^{\mathrm{A}, \mathrm{a}}$ & $81.2 \pm 0.7^{\mathrm{A}, \mathrm{a}}$ & $81.1 \pm 1.0^{\mathrm{A}, \mathrm{a}}$ & $0.1 \pm 0.2^{\mathrm{A}, \mathrm{g}}$ & $0.1 \pm 0.2^{\mathrm{A}, \mathrm{g}}$ & $15.4 \pm 0.9 \mathrm{~A}, \mathrm{a}$ & $15.6 \pm 0.8^{\mathrm{A}, \mathrm{a}}$ \\
\hline \multirow{5}{*}{24} & 0 & $6.6 \pm 0.1 \mathrm{~A}, \mathrm{a}$ & $6.5 \pm 0.0^{\mathrm{A}, \mathrm{a}}$ & $81.1 \pm 1.1^{\mathrm{A}, \mathrm{a}}$ & $81.0 \pm 1.1^{\mathrm{A}, \mathrm{a}}$ & $2.2 \pm 0.6^{\mathrm{A}, \mathrm{c}}$ & $2.1 \pm 0.4^{\mathrm{A}, \mathrm{c}}$ & $15.5 \pm 0.8^{\mathrm{A}, \mathrm{d}}$ & $15.3 \pm 0.7^{\mathrm{A}, \mathrm{d}}$ \\
\hline & 1 & $6.6 \pm 0.1 \mathrm{~A}, \mathrm{a}$ & $6.5 \pm 0.2^{\mathrm{A}, \mathrm{a}}$ & $80.0 \pm 1.2^{\mathrm{A}, \mathrm{b}}$ & $80.2 \pm 1.1^{\mathrm{A}, \mathrm{b}}$ & $2.3 \pm 0.4^{\mathrm{A}, \mathrm{c}}$ & $2.3 \pm 0.2^{\mathrm{A}, \mathrm{c}}$ & $16.4 \pm 0.8^{\mathrm{A}, \mathrm{c}}$ & $16.7 \pm 1.2^{\mathrm{A}, \mathrm{c}}$ \\
\hline & 2 & $6.6 \pm 0.1 \mathrm{~A}, \mathrm{a}$ & $6.5 \pm 0.1^{\mathrm{A}, \mathrm{a}}$ & $78.7 \pm 1.1^{\mathrm{A}, \mathrm{c}}$ & $78.7 \pm 1.3^{\mathrm{A}, \mathrm{c}}$ & $2.5 \pm 0.4^{\mathrm{A}, \mathrm{bc}}$ & $2.5 \pm 0.4^{\mathrm{A}, \mathrm{bc}}$ & $16.9 \pm 0.9 \mathrm{~A}, \mathrm{c}$ & $16.7 \pm 0.8^{\mathrm{A}, \mathrm{c}}$ \\
\hline & 3 & $6.6 \pm 0.1 \mathrm{~A}, \mathrm{a}$ & $6.5 \pm 0.2^{\mathrm{A}, \mathrm{a}}$ & $77.8 \pm 1.5^{\mathrm{A}, \mathrm{d}}$ & $77.8 \pm 1.6^{\mathrm{A}, \mathrm{d}}$ & $2.7 \pm 0.4^{\mathrm{A}, \mathrm{b}}$ & $2.7 \pm 0.4^{\mathrm{A}, \mathrm{b}}$ & $18.2 \pm 1.0^{\mathrm{A}, \mathrm{b}}$ & $18.6 \pm 1.2^{\mathrm{A}, \mathrm{b}}$ \\
\hline & 5 & $6.5 \pm 0.2^{\mathrm{A}, \mathrm{a}}$ & $6.6 \pm 0.2^{\mathrm{A}, \mathrm{a}}$ & $77.0 \pm 1.3^{\mathrm{A}, \mathrm{d}}$ & $76.7 \pm 1.4^{\mathrm{A}, \mathrm{d}}$ & $3.8 \pm 0.6^{\mathrm{A}, \mathrm{a}}$ & $3.8 \pm 0.6^{\mathrm{A}, \mathrm{a}}$ & $20.4 \pm 1.6^{\mathrm{A}, \mathrm{a}}$ & $20.7 \pm 1.8^{\mathrm{A}, \mathrm{a}}$ \\
\hline
\end{tabular}

Data represent the means of 12 measurements with standard deviations. Means followed by the same lower-case letter within a column are not significantly different at each temperature at

$4{ }^{\circ} \mathrm{C}$ and $24^{\circ} \mathrm{C}\left(p>0.05\right.$. Tukey's test), respectively. Means followed by the same capital letter within a row are not significantly different between samples in the same property at $4{ }^{\circ} \mathrm{C}$ and

$24^{\circ} \mathrm{C}$. The ADCP treatment voltage and time were $24 \mathrm{kV}$ and $3 \mathrm{~min}$, respectively. 
The color of chicken products is a main factor that determines product acceptability by customers [47]. As shown during storage at $4{ }^{\circ} \mathrm{C}$ and $24{ }^{\circ} \mathrm{C}$, the color of $\mathrm{CBC}$ changed with increasing storage period regardless of ADCP treatment (Table 5), while no significant differences were observed between untreated and ADCP-treated CBCs $(p>0.05)$. The reactive species generated during cold plasma treatment interact with food product components to alter the color. Furthermore, ozone generally present in ADCP may lead to bleaching of food [48]. However, potential changes in CBC following ADCP treatment was not observed in this study. This may be because the treatment did not generate reactive species in quantities that were sufficient to alter the color of CBC. Some studies also reported the absence of changes in the color of plasma-treated meat and meat products, such as fresh chicken breast [49], dry-cured beef [50], and processed chicken breasts [16]. The insignificance of color change during storage may also be due to the WPI coating on CBCs, which reduces the chance of reaction between reactive species and meat, which in turn reduces the possibility of a color change being induced in $\mathrm{CBC}$. However, an insignificant change in the color of uncoated CBCs immediately following the ADCP treatment at $39 \mathrm{kV}$ for $3.5 \mathrm{~min}$ has been reported previously [8], implying that ADCP treatment in the current study did not alter the color regardless of WPI coating.

\subsubsection{TVBN}

TVBN measures the total amount of amines and ammonia produced upon the decomposition of meat, and thus, acts as an indicator of meat freshness [51]. TVBN of CBCs during storage following ADCP treatment is shown (Table 6). The reactive species of ADCP and amino acids lead to interactions resulting in the loss of $\alpha$-helix and $\beta$-sheet, causing protein denaturation $[52,53]$. However, the TVBN of CBCs following ADCP treatment did not show significant differences $(p>0.05)$, indicating that the reactive species generated during $\mathrm{ADCP}$ treatment caused no significant protein denaturation in CBCs. These results may be due to reactive species generated being insufficient to induce protein denaturation in $\mathrm{CBC}$ s or because the WPI coating on CBCs acts as a barrier to prevent the reactive species from directly influencing chicken breasts, as described above.

Across all storage temperatures, TVBN displayed an increasing trend in ADCP-untreated and ADCP-treated CBCs, and this increase in TVBN during storage may be attributed to protein decomposition, due to microorganisms [54]. During storage at $24{ }^{\circ} \mathrm{C}$, an increase in TVBN was exhibited from $2 \mathrm{~d}$ onwards, which may be due to the rapid increase in indigenous mesophilic bacteria in $\mathrm{CBCs}$ at identical storage temperatures, facilitating protein decomposition (Figure 1A).

\subsubsection{TBARS}

Results of the TBARS assay for lipid oxidation in ADCP-untreated and ADCP-treated CBCs stored at 4 and $24^{\circ} \mathrm{C}$ are presented (Table 6). The TBARS values related to ADCP treatment during storage were not significantly different $(p>0.05)$. ROS generated during ADCP treatment act as a main factor that facilitates lipid oxidation [55]. Chicken breast has lower lipid content than red meat, such as beef or pork, so that it is more stable against oxidation induced by cold plasma and acts as an ideal candidate for cold plasma treatment $[8,56,57]$. The WPI coating on CBC may play a role in preventing a direct reaction between cold plasma-reactive species and the lipids of CBC. However, the insignificant change observed in the level of lipid oxidation may be more due to insufficient lipid reactants or reactive species than due to the coating. The results of a previous study of ours revealed that the ADCP treatment ( $39 \mathrm{kV}$ for $3.5 \mathrm{~min}$ ) did not significantly increase the lipid oxidation level of uncoated $\mathrm{CBC}$, immediately following the treatment [8]. 
Table 6. Effects of atmospheric dielectric barrier discharge cold plasma (ADCP) treatment on the lipid oxidation and total volatile basic nitrogen (TVBN) of chicken breast cubes during storage at 4 and $24^{\circ} \mathrm{C}$.

\begin{tabular}{|c|c|c|c|c|c|c|c|}
\hline \multirow{2}{*}{$\begin{array}{c}\text { Storage } \\
\text { Temperature } \\
\left({ }^{\circ} \mathrm{C}\right)\end{array}$} & \multirow{2}{*}{$\begin{array}{l}\text { Storage Time } \\
\text { (d) }\end{array}$} & \multicolumn{2}{|c|}{ TBARS } & \multicolumn{2}{|c|}{ TVBN } & \multicolumn{2}{|c|}{ Tenderness } \\
\hline & & Untreated & ADCP-Treated & Untreated & ADCP-Treated & Untreated & ADCP-Treated \\
\hline \multirow[t]{7}{*}{ (- ) } & 0 & $4.9 \pm 0.3^{\mathrm{A}, \mathrm{b}}$ & $4.9 \pm 0.3^{\mathrm{A}, \mathrm{b}}$ & $4.4 \pm 1.4^{\mathrm{A}, \mathrm{e}}$ & $4.4 \pm 1.6^{\mathrm{A}, \mathrm{e}}$ & $2466.9 \pm 776.2^{\mathrm{A}, \mathrm{a}}$ & $2545.3 \pm 879.6^{\mathrm{A}, \mathrm{a}}$ \\
\hline & 3 & $4.8 \pm 0.3^{\mathrm{A}, \mathrm{b}}$ & $4.8 \pm 0.3^{\mathrm{A}, \mathrm{b}}$ & $6.7 \pm 1.1^{\mathrm{A}, \mathrm{d}}$ & $6.8 \pm 1.4 \mathrm{~A}, \mathrm{~d}$ & $2584.4 \pm 528.7 \mathrm{~A}, \mathrm{a}$ & $2417.3 \pm 802.5^{\mathrm{A}, \mathrm{a}}$ \\
\hline & 5 & $4.8 \pm 0.3 \mathrm{~A}, \mathrm{~b}$ & $4.8 \pm 0.3^{\mathrm{A}, \mathrm{b}}$ & $7.5 \pm 1.8^{\mathrm{A}, \mathrm{cd}}$ & $7.5 \pm 1.8^{\mathrm{A}, \mathrm{cd}}$ & $2509.2 \pm 454.7^{\mathrm{A}, \mathrm{a}}$ & $2803.1 \pm 785.5^{\mathrm{A}, \mathrm{a}}$ \\
\hline & 7 & $4.9 \pm 0.3^{\mathrm{A}, \mathrm{b}}$ & $4.9 \pm 0.5^{\mathrm{A}, \mathrm{b}}$ & $10.9 \pm 1.6^{\mathrm{A}, \mathrm{c}}$ & $10.2 \pm 2.9 \mathrm{~A}, \mathrm{c}$ & $2789.8 \pm 584.4 \mathrm{~A}, \mathrm{a}$ & $2834.9 \pm 792.0 \mathrm{~A}, \mathrm{a}$ \\
\hline & 10 & $4.9 \pm 0.5^{\mathrm{A}, \mathrm{b}}$ & $4.9 \pm 0.3^{\mathrm{A}, \mathrm{b}}$ & $8.6 \pm 1.9^{\mathrm{A}, \mathrm{b}}$ & $8.6 \pm 1.5^{\mathrm{A}, \mathrm{b}}$ & $2955.1 \pm 794.7^{\mathrm{A}, \mathrm{a}}$ & $2911.9 \pm 607.3^{\mathrm{A}, \mathrm{a}}$ \\
\hline & 14 & $4.8 \pm 0.4^{\mathrm{A}, \mathrm{b}}$ & $4.9 \pm 0.4^{\mathrm{A}, \mathrm{b}}$ & $10.9 \pm 1.7^{\mathrm{A}, \mathrm{b}}$ & $10.7 \pm 1.9^{\mathrm{A}, \mathrm{a}}$ & $2972.2 \pm 628.2 \mathrm{~A}, \mathrm{a}$ & $2951.5 \pm 521.1^{\mathrm{A}, \mathrm{a}}$ \\
\hline & 21 & $5.5 \pm 0.2^{\mathrm{A}, \mathrm{a}}$ & $5.5 \pm 0.2^{\mathrm{A}, \mathrm{a}}$ & $13.6 \pm 1.7^{\mathrm{A}, \mathrm{a}}$ & $13.3 \pm 1.4^{\mathrm{A}, \mathrm{a}}$ & $2884.0 \pm 386.7^{\mathrm{A}, \mathrm{a}}$ & $2942.4 \pm 526.4^{\mathrm{A}, \mathrm{a}}$ \\
\hline \multirow{5}{*}{24} & 0 & $4.9 \pm 0.3^{\mathrm{A}, \mathrm{c}}$ & $4.9 \pm 0.3^{\mathrm{A}, \mathrm{c}}$ & $4.4 \pm 1.4^{\mathrm{A}, \mathrm{c}}$ & $4.4 \pm 1.6^{\mathrm{A}, \mathrm{c}}$ & $2466.9 \pm 776.2^{\mathrm{A}, \mathrm{a}}$ & $2545.3 \pm 879.6^{\mathrm{A}, \mathrm{a}}$ \\
\hline & 1 & $5.8 \pm 0.4^{\mathrm{A}, \mathrm{c}}$ & $5.7 \pm 0.4^{\mathrm{A}, \mathrm{c}}$ & $7.7 \pm 0.7^{\mathrm{A}, \mathrm{b}}$ & $7.8 \pm 0.8^{\mathrm{A}, \mathrm{b}}$ & $2513.4 \pm 781.8^{\mathrm{A}, \mathrm{a}}$ & $2549.4 \pm 650.2 \mathrm{~A}, \mathrm{a}$ \\
\hline & 2 & $9.4 \pm 1.6^{\mathrm{A}, \mathrm{b}}$ & $9.9 \pm 1.7^{\mathrm{A}, \mathrm{b}}$ & $9.2 \pm 1.5^{\mathrm{A}, \mathrm{b}}$ & $9.2 \pm 1.4^{\mathrm{A}, \mathrm{b}}$ & $2013.9 \pm 595.4^{\mathrm{A}, \mathrm{ab}}$ & $2067.5 \pm 475.1 \mathrm{~A}, \mathrm{a}, \mathrm{b}$ \\
\hline & 3 & $10.2 \pm 1.3^{\mathrm{A}, \mathrm{b}}$ & $10.2 \pm 0.9^{\mathrm{A}, \mathrm{b}}$ & $11.6 \pm 1.3^{\mathrm{A}, \mathrm{a}}$ & $11.3 \pm 0.9 \mathrm{~A}, \mathrm{a}$ & $1572.6 \pm 624.2^{\mathrm{A}, \mathrm{bc}}$ & $1575.7 \pm 580.1 \mathrm{~A}, \mathrm{~b}, \mathrm{c}$ \\
\hline & 5 & $14.1 \pm 2.2^{\mathrm{A}, \mathrm{a}}$ & $14.2 \pm 2.8 \mathrm{~A}, \mathrm{a}$ & $11.3 \pm 3^{\mathrm{A}, \mathrm{a}}$ & $11.5 \pm 2.7^{\mathrm{A}, \mathrm{a}}$ & $1265.5 \pm 438.7^{\mathrm{A}, \mathrm{c}}$ & $1215.5 \pm 477.7 \mathrm{~A}, \mathrm{c}$ \\
\hline
\end{tabular}

Data represent the means of 12 measurements with standard deviations. Means followed by the same lower-case letter within a column are not significantly different at each temperature at $4{ }^{\circ} \mathrm{C}$ and $24^{\circ} \mathrm{C}\left(p>0.05\right.$. Tukey's test), respectively. Means followed by the same capital letter within a row are not significantly different between samples in the same property at $4{ }^{\circ} \mathrm{C}$ and $24{ }^{\circ} \mathrm{C}$. The ADCP treatment voltage and time were $24 \mathrm{kV}$ and $3 \mathrm{~min}$, respectively. 


\subsubsection{Tenderness}

No significant difference in tenderness following ADCP treatment was found across all storage temperatures $(p>0.05)$; (Table 6$)$. ROS generated by cold plasma may react with the side chains of amino acids, causing protein oxidation and affecting tenderness [58]. The results imply that potential reactive species in $\mathrm{ADCP}$ could react with the WPI coating surface mainly without altering the texture of $\mathrm{CBC}$ s on the whole. During storage at $4{ }^{\circ} \mathrm{C}$, a trend towards preserving tenderness was shown during the entire storage period. By contrast, tenderness was found to have decreased with increasing storage period during storage at $24{ }^{\circ} \mathrm{C}$. This may be due to protein decomposition caused by the proliferation of indigenous mesophilic bacteria during storage at $24^{\circ} \mathrm{C}$, a temperature higher than $4{ }^{\circ} \mathrm{C}$ [59]. Therefore, these results confirmed that storage at refrigeration temperatures is a method that preserves the tenderness of ADCP-treated RTE chicken meat.

\subsubsection{Sensory Evaluation}

Sensory evaluation of ADCP-untreated and ADCP-treated CBCs stored at $4{ }^{\circ} \mathrm{C}$ for 0 and $3 \mathrm{~d}$ was conducted using a 9-point scale (Table 7). Unstored samples showed no significant differences in color and appearance among sensory properties, excluding flavor, in response to ADCP treatment $(p>0.05)$. Regarding differences in flavor preference, lower preference towards ADCP-treated CBCs may be attributed to the possibility that the reactive species generated during cold plasma treatment may add a foreign flavor to the meat and meat products [60]. However, in samples that had been stored for $3 \mathrm{~d}$, preference differences related to ADCP treatment had disappeared with the changes in other quality properties during storage $(p>0.05)$. Thus, the results indicated that deterioration in the flavor of CBCs during storage was not accelerated by ADCP treatment, and considering the time taken for RTE meat products to reach consumers post-packaging cold plasma treatment, the initial flavor associated with $\mathrm{ADCP}$ treatment is considered not to be an issue.

Table 7. Effects of atmospheric dielectric barrier discharge cold plasma (ADCP) treatment on the sensory attributes of chicken breast cubes with 3-day storage at $4{ }^{\circ} \mathrm{C}$.

\begin{tabular}{ccccc}
\hline \multirow{2}{*}{ Samples } & & \multicolumn{3}{c}{ Sensory Attributes } \\
\cline { 3 - 5 } & & Color & Flavor & Appearance \\
\hline \multirow{2}{*}{ Un-stored } & Untreated & $6.0 \pm 1.3^{\mathrm{a}}$ & $6.3 \pm 1.4^{\mathrm{a}}$ & $6.2 \pm 1.4^{\mathrm{a}}$ \\
& ADCP-treated & $5.8 \pm 1.6^{\mathrm{a}}$ & $5.4 \pm 1.5^{\mathrm{b}}$ & $6.1 \pm 1.8^{\mathrm{a}}$ \\
\hline \multirow{2}{*}{ 3-day storage at $4{ }^{\circ} \mathrm{C}$} & Untreated & $5.9 \pm 1.7^{\mathrm{a}}$ & $5.3 \pm 1.2^{\mathrm{a}}$ & $6.2 \pm 1.7^{\mathrm{a}}$ \\
& ADCP-treated & $5.4 \pm 1.6^{\mathrm{a}}$ & $5.6 \pm 1.3^{\mathrm{a}}$ & $5.7^{\mathrm{a}} \pm 1.7^{\mathrm{a}}$ \\
\hline
\end{tabular}

Values are expressed as mean \pm standard deviation. Means followed by the same lower-case letter within a column are not significantly different at each storage day $(p>0.05$. Tukey's test), respectively. The ADCP treatment voltage and time were $24 \mathrm{kV}$ and $3 \mathrm{~min}$, respectively.

\section{Conclusions}

ADCP treatment of CBCs packaged in PET containers was conducted under $24 \mathrm{kV}$ for $3 \mathrm{~min}$. Under such conditions, ADCP treatment reduced indigenous mesophilic bacteria, Salmonella, and TV in CBCs by $0.70 \pm 0.12 \log$ CFU/cube, $1.45 \pm 0.05 \log$ CFU/cube, and $1.08 \pm 0.15 \log$ PFU/cube, respectively. The nitrate content of CBCs showed a significant increase immediately following the ADCP treatment, whereas the nitrite content showed no significant difference. Acute and subacute toxicity tests confirmed that ADCP treatment was safe. Indigenous mesophilic bacteria and Salmonella in ADCP treated CBCs stored at $4{ }^{\circ} \mathrm{C}$ were reduced by $0.7-0.9$ and 1.4-1.7 $\log \mathrm{CFU} /$ cube, respectively, which was maintained during a steady decrease. ADCP treatment did not exert a significant influence on the $\mathrm{pH}$, color, TVBN, lipid oxidation, and tenderness of CBCs across all storage temperatures. Although a significant fall in flavor preference was observed immediately following the ADCP treatment, it is not expected to cause an issue when the processing stage is taken into account. Thus, the current 
study verified the potential of $\mathrm{ADCP}$ to enhance the microbial safety of $\mathrm{CBCs}$, while maintaining their toxicological safety and preserving the quality and sensory properties.

Author Contributions: Conceptualization, S.C.M. and C.-I.C.; methodology, E.S.L. and S.C.M.; validation, E.S.L., J.H.K., and S.Y.L.; formal analysis, E.S.L., J.H.K., and S.Y.L.; investigation, E.S.L. and C.-I.C.; data curation, E.S.L. and C.-I.C.; writing-original draft preparation, E.S.L. and C.-I.C.; writing-review and editing, E.S.L., C.-I.C., S.C.M.; visualization, E.S.L. and C.-I.C.; supervision, S.C.M.; project administration, S.C.M.; funding acquisition, S.C.M. All authors have read and agreed to the published version of the manuscript.

Funding: This research was supported by the National Research Foundation of Korea (NRF) grant funded by the Korea government (MSIT) (No. 2019R1A2B5B01069364) and by Korea Institute of Planning and Evaluation for Technology in Food, Agriculture and Forestry (IPET) through High Value-added Food Technology Development Program, funded by Ministry of Agriculture, Food and Rural Affairs (MAFRA) (318026-03).

Conflicts of Interest: The authors declare no conflict of interest.

\section{References}

1. Moutiq, R.; Misra, N.N.; Mendonca, A.; Keener, K. In-package decontamination of chicken breast using cold plasma technology: Microbial, quality and storage studies. Meat Sci. 2020, 159, 107942. [CrossRef] [PubMed]

2. Yang, X.; Huang, J.; Wum, Q.; Zhang, J.; Liu, S.; Guo, W.; Cai, S.; Yu, S. Prevalence, antimicrobial resistance and genetic diversity of Salmonella isolated from retail ready-to-eat foods in China. Food Control 2016, 60, 50-56. [CrossRef]

3. Centers for Disease Control and Prevention (CDC). Foodborne Outbreak Online Database (FOOD Tool). Available online: https://wwwn.cdc.gov/norsdashboard/ (accessed on 30 October 2019).

4. Kim, S.Y.; Bang, I.H.; Min, S.C. Effects of packaging parameters on the inactivation of Salmonella contaminating mixed vegetables in plastic packages using atmospheric dielectric barrier discharge cold plasma treatment. J. Food Eng. 2019, 242, 55-67. [CrossRef]

5. Min, S.C.; Roh, S.H.; Boyd, G.; Sites, J.E.; Uknalis, J.; Fan, X.; Niemira, B.A. Inactivation of Escherichia coli O157:H7 and aerobic microorganisms in romaine lettuce packaged in a commercial polyethylene terephthalate container using atmospheric cold plasma. J. Food Prot. 2017, 80, 35-43. [CrossRef]

6. Min, S.C.; Roh, S.H.; Niemira, B.A.; Boyd, G.; Sites, J.E.; Uknalis, J.; Fan, X. In-package inhibition of E. coli O157:H7 on bulk Romaine lettuce using cold plasma. Food Microbiol. 2017, 65, 1-6. [CrossRef]

7. Misra, N.N.; Yepez, X.; Xub, L.; Keener, K. In-package cold plasma technologies. J. Food Eng. 2019, 244, 21-31. [CrossRef]

8. Roh, S.H.; Oh, Y.J.; Lee, S.Y.; Kang, J.H.; Min, S.C. Inactivation of Escherichia coli O157:H7, Salmonella, Listeria monocytogenes, and Tulane virus in processed chicken breast via atmospheric in-package cold plasma treatment. LWT Food Sci. Technol. 2020, 127, 109429. [CrossRef]

9. Min, S.C.; Roh, S.H.; Niemira, B.A.; Sites, J.E.; Boyd, G.; Lacombe, A. Dielectric barrier discharge atmospheric cold plasma inhibits Escherichia coli O157:H7, Salmonella, Listeria monocytogenes, and Tulane virus in Romaine lettuce. Int. J. Food Microbiol. 2016, 237, 114-120. [CrossRef] [PubMed]

10. Pignata, C.; D'angelo, D.; Fea, E.; Gilli, G. A review on microbiological decontamination of fresh produce with nonthermal plasma. J. Appl. Microbiol. 2017, 122, 1438-1455. [CrossRef] [PubMed]

11. Arjunan, K.; Sharma, V.; Ptasinska, S. Effects of atmospheric pressure plasmas on isolated and cellular DNA-A review. Int. J. Mol. Sci. 2015, 16, 2971-3016. [CrossRef]

12. Sarangapani, C.; Patange, A.; Bourke, P.; Keener, K.; Cullen, P.J. Recent advances in the application of cold plasma technology in foods. Annu. Rev. Food Sci. Technol. 2018, 9, 609-629. [CrossRef]

13. Han, S.H.; Suh, H.J.; Hong, K.B.; Kim, S.Y.; Min, S.C. Oral toxicity of cold plasma-treated edible films for food coating. J. Food Sci. 2016, 81, 3052-3057. [CrossRef] [PubMed]

14. Wende, K.; Bekeschus, S.; Schmidt, A.; Jatsch, L.; Hasse, S.; Weltmann, K.D.; Masur, K.; Woedtke, T. Risk assessment of a cold argon plasma jet in respect to its mutagenicity. Mutat. Res. Genet. Toxicol. Environ. Mutagen. 2016, 798-799, 48-54. [CrossRef] [PubMed]

15. Wang, J.M.; Zhuang, H.; Lawrence, K.; Zhang, J.H. Disinfection of chicken fillets in packages with atmospheric cold plasma: Effects of treatment voltage and time. J. Appl. Microbiol. 2018, 124, 1212-1219. [CrossRef] 
16. Roh, S.H.; Lee, S.Y.; Park, H.H.; Lee, E.S.; Min, S.C. Effects of the treatment parameters on the efficacy of the inactivation of Salmonella contaminating boiled chicken breast by in-package atmospheric cold plasma treatment. Int. J. Food Microbiol. 2019, 293, 24-33. [CrossRef]

17. McHugh, T.H.; Krochta, J.M. Sorbitol-vs glycerol-plasticized whey protein edible films: Integrated oxygen permeability and tensile property evaluation. J. Agric. Food Chem. 1994, 42, 841-845. [CrossRef]

18. Lacombe, A.; Niemira, B.A.; Gurtler, J.B.; Sites, J.; Boyd, G.; Kingsley, D.H.; Li, X.; Chen, H. Nonthermal inactivation of norovirus surrogates on blueberries using atmospheric cold plasma. Food Microbiol. 2017, 63, 1-5. [CrossRef]

19. Li, X.; Ye, M.; Neetoo, H.; Golovan, S.; Chen, H. Pressure inactivation of Tulane virus, a candidate surrogate for human norovirus and its potential application in food industry. Int. J. Food Microbiol. 2013, 162, 37-42. [CrossRef]

20. Min, S.C.; Roh, S.H.; Niemira, B.A.; Boyd, G.; Sites, J.E.; Fan, X.; Sokorai, K.; Jin, T.Z. In-package atmospheric cold plasma treatment of bulk grape tomatoes for microbiological safety and preservation. Food Res. Int. 2018, 108, 378-386. [CrossRef]

21. Chou, S.S.; Chung, J.C.; Hwang, D.F. A high performance liquid chromatography method for determining nitrate and nitrite levels in vegetables. J. Food Drug Anal. 2003, 11, 233-238. [CrossRef]

22. Hsu, J.; Arcot, J.; Lee, N.A. Nitrate and nitrite quantification from cured meat and vegetables and their estimated dietary intake in Australians. Food Chem. 2009, 115, 334-339. [CrossRef]

23. Lee, H.; Kim, M.S.; Lee, W.H.; Cho, B.K. Determination of the total volatile basic nitrogen (TVB-N) content in pork meat using hyperspectral fluorescence imaging. Sens. Actuator B Chem. 2018, 259, 532-539. [CrossRef]

24. Lund, M.N.; Hviid, M.S.; Skibsted, L.H. The combined effect of antioxidants and modified atmosphere packaging on protein and lipid oxidation in beef patties during chill storage. Meat Sci. 2007, 76, $226-233$. [CrossRef]

25. Barbanti, D.; Pasquini, M. Influence of cooking conditions on cooking loss and tenderness of raw and marinated chicken breast meat. LWT Food Sci. Technol. 2005, 38, 895-901. [CrossRef]

26. Albertos, I.; Martín-Diana, A.B.; Cullen, P.J.; Tiwari, B.K.; Ojha, S.K.; Bourke, P.; Alvarez, C.; Rico, D. Effects of dielectric barrier discharge (DBD) generated plasma on microbial reduction and quality parameters of fresh mackerel (Scomber scombrus) fillets. Innov. Food Sci. Emerg. Technol. 2017, 44, 117-122. [CrossRef]

27. Pankaj, S.K.; Bueno-Ferrer, C.; Misra, N.N.; Milosavljevic, V.; O’Donnel, C.P.; Bourke, P.; Keener, K.M.; Cullen, P.J. Application of cold plasma technology in food packaging. Trends Food Sci. Technol. 2014, 35, 5-17. [CrossRef]

28. Bae, S.C.; Park, S.Y.; Choe, W.; Ha, S.D. Inactivation of murine norovirus-1 and hepatitis A virus on fresh meats by atmospheric pressure plasma jets. Food Res. Int. 2015, 76, 342-347. [CrossRef]

29. Ahlfeld, B.; Li, Y.; Boulaaba, A.; Binder, A.; Schotte, U.; Zimmermann, J.L.; Morfill, G.; Klein, G. Inactivation of a foodborne norovirus outbreak strain with nonthermal atmospheric pressure plasma. mBio 2015, 6, e020300-e020314. [CrossRef]

30. Le Roy, G.; Embury, J.D.; Edwards, G.; Ashby, M.F. A model of ductile fracture based on the nucleation and growth of voids. Acta Metall. 1981, 29, 1509-1522. [CrossRef]

31. Wu, Y.; Liang, Y.; Wei, K.; Li, W.; Yao, M.; Zhang, J.; Grinshpun, S.A. MS2 virus inactivation by atmospheric-pressure cold plasma using different gas carriers and power levels. Appl. Environ. Microbiol. 2015, 81, 996-1002. [CrossRef]

32. Bourke, P.; Ziuzina, D.; Boehm, D.; Cullen, P.J.; Keener, K. The potential of cold plasma for safe and sustainable food production. Trends Biotechnol. 2018, 36, 615-626. [CrossRef] [PubMed]

33. Jung, S.; Lee, J.; Lim, Y.; Choe, W.; Yong, H.I.; Jo, C. Direct infusion of nitrite into meat batter by atmospheric pressure plasma treatment. Innov. Food Sci. Emerg. Technol. 2017, 39, 113-118. [CrossRef]

34. Yong, H.I.; Lee, S.H.; Kim, S.Y.; Park, S.; Park, J.; Choe, W.; Jo, C. Color development physiochemical properties, and microbiological safety of pork jerky processed with atmospheric pressure plasma. Innov. Food Sci. Emerg. Technol. 2019, 53, 78-84. [CrossRef]

35. Zhang, H.; Xu, Z.; Shen, J.; Li, X.; Ding, L.; Ma, J.; Lan, Y.; Xia, W.; Cheng, C.; Sun, Q.; et al. Effects and mechanism of atmospheric pressure dielectric barrier discharge cold plasma on lactate dehydrogenase (LDH) enzyme. Sci. Rep. 2015, 5, 10031. [CrossRef] 
36. Patange, A.; Boehm, D.; Giltrap, M.; Lu, P.; Cullen, P.J.; Bourke, P. Assessment of the disinfection capacity and eco-toxicological impact of atmospheric cold plasma for treatment of food industry effluents. Sci. Total Environ. 2018, 631-632, 298-307. [CrossRef]

37. Oehmigen, K.; Hahnel, M.; Brandenburg, R.; Wilke, C.; Weltmann, K.D.; Woedtke, T. The role of acidification for antimicrobial activity of atmospheric pressure plasma in liquids. Plasma Process. Polym. 2010, 7, 3-4. [CrossRef]

38. Li, X.; Luo, Y.; Wang, L.; Li, Y.; Shi, Y.; Cui, Y.; Xue, M. Acute and subacute toxicity of ethanol extracts from Salvia przewalskii Maxim in rodents. J. Ethnopharmacol. 2010, 131, 110-115. [CrossRef]

39. Lameire, N.; Van Biesen, W.; Vanholder, R. Acute renal failure. Lancet 2005, 365, 417-430. [CrossRef]

40. Piao, Y.; Liu, Y.; Xie, X. Change trends of organ weight background data in Sprague-Dawley rats at different ages. J. Toxicol. Pathol. 2013, 26, 29-34. [CrossRef]

41. Ziuzina, D.; Patil, S.; Cullen, P.J.; Keener, K.M.; Bourke, P. Atmospheric cold plasma inactivation of Escherichia coli, Salmonella enterica serovar Typhimurium and Listeria monocytogenes inoculated on fresh produce. Food Microbiol. 2014, 42, 109-116. [CrossRef]

42. Pankaj, S.K.; Wan, Z.; Keener, K.M. Effects of cold plasma on food quality: A review. Foods 2018, 7, 4. [CrossRef] [PubMed]

43. Kim, B.; Yun, H.; Jung, S.; Jung, Y.; Jung, H.; Choe, W.; Jo, C. Effect of atmospheric pressure plasma on inactivation of pathogens inoculated onto bacon using two different gas compositions. Food Microbiol. 2011, 28, 9-13. [CrossRef]

44. Ulbin-Figlewicz, N.; Brychcy, E.; Jarmoluk, A. Effect of low-pressure cold plasma on surface microflora of meat and quality attributes. J. Food Sci. Technol. 2015, 52, 1228-1232. [CrossRef] [PubMed]

45. Morent, R.; De Geyter, N.; Desmet, T.; Dubruel, P.; Leys, C. Plasma surface modification of biodegradable polymers: A review. Plasma Process. Polym. 2011, 8, 171-190. [CrossRef]

46. Xiong, Z.; Du, T.; Lu, X.; Cao, Y.; Pan, Y. How deep can plasma penetrate into a biofilm? Appl. Phys. Lett. 2011, 98, 221503. [CrossRef]

47. Sáyago-Ayerdi, S.G.A.; Brenes, A.; Goñi, I. Effect of grape antioxidant dietary fiber on the lipid oxidation of raw and cooked chicken hamburgers. LWT Food Sci. Technol. 2009, 42, 971-976. [CrossRef]

48. Misra, N.N.; Moiseev, T.; Patil, S.; Pankaj, S.K.; Bourke, P.; Mosnier, J.P.; Keener, K.M.; Cullen, P.J. Cold plasma in modified atmospheres for post-harvest treatment of strawberries. Food Bioprocess Technol. 2014, 7, 3045-3054. [CrossRef]

49. Wang, J.; Zhuang, H.; Hinton, A., Jr.; Zhang, J. Influence of in-package cold plasma treatment on microbiological shelf life and appearance of fresh chicken breast fillets. Food Microbiol. 2016, 60, 142-146. [CrossRef]

50. Rød, S.K.; Hansen, F.; Leipold, F.; Knøchel, S. Cold atmospheric pressure plasma treatment of ready-to-eat meat: Inactivation of Listeria innocua and changes in product quality. Food Microbiol. 2012, 30, 233-238. [CrossRef]

51. Kruk, Z.A.; Yun, H.; Rutley, D.L.; Lee, E.J.; Kim, Y.J.; Jo, C. The effect of high pressure on microbial population, meat quality and sensory characteristics of chicken breast fillet. Food Control 2011, 22, 6-12. [CrossRef]

52. Li, Y.; Kojtari, A.; Friedman, G.; Brooks, A.D.; Fridman, A.; Ji, H.F. Decomposition of L-valine under nonthermal dielectric barrier discharge plasma. J. Phys. Chem. B 2014, 118, 1612-1620. [CrossRef] [PubMed]

53. Segat, A.; Misra, N.N.; Cullen, P.J.; Innocente, N. Effect of atmospheric pressure cold plasma (ACP) on activity and structure of alkaline phosphatase. Food Bioprod. Process. 2016, 98, 181-188. [CrossRef]

54. Cai, J.; Chen, Q.; Wan, X.; Zhaom, J. Determination of total volatile basic nitrogen (TVB-N) content and Warner-Bratzler shear force (WBSF) in pork using Fourier transform near infrared (FT-NIR) spectroscopy. Food Chem. 2011, 126, 1354-1360. [CrossRef]

55. Min, B.; Ahn, D.U. Mechanism of lipid peroxidation in meat and meat products-A review. Food Sci. Biotechnol. 2005, 14, 152-163.

56. Park, S.Y.; Ha, S.D. Ultraviolet-C radiation on the fresh chicken breast: Inactivation of major foodborne viruses and changes in physicochemical and sensory qualities of product. Food Bioprocess Technol. 2015, 8, 895-906. [CrossRef]

57. Lee, H.; Yong, H.I.; Kim, H.J.; Choe, W.; Yoo, S.J.; Jang, E.J. Evaluation of the microbiological safety, quality changes, and genotoxicity of chicken breast treated with flexible thin-layer dielectric barrier discharge plasma. Food Sci. Biotechnol. 2016, 25, 1189-1195. [CrossRef] 
58. Lund, M.N.; Heinonen, M.; Baron, C.P.; Estevez, M. Protein oxidation in muscle foods: A review. Mol. Nutr. Food Res. 2011, 55, 83-95. [CrossRef]

59. Clausen, I.; Jakobsen, M.; Ertbjerg, P.; Madsen, N.T. Modified atmosphere packaging affects lipid oxidation, myofibrillar fragmentation index and eating quality of beef. Packag. Technol. Sci. 2009, 22, 85-96. [CrossRef]

60. Ahn, D.U.; Lee, E.J.; Feng, X.; Zhang, W.; Lee, J.H.; Jo, C.; Nam, K.C. Mechanisms of volatile production from sulfur-containing amino acids by irradiation. Radiat. Phys. Chem. 2016, 119, 80-84. [CrossRef]

(C) 2020 by the authors. Licensee MDPI, Basel, Switzerland. This article is an open access article distributed under the terms and conditions of the Creative Commons Attribution (CC BY) license (http://creativecommons.org/licenses/by/4.0/). 